\title{
Safe Work Practices for Working with Wildlife
}

Chapter 2 of

Section C, Techniques in Disease Surveillance and Investigation Book 15, Field Manual of Wildlife Diseases

Techniques and Methods 15-C2 



\section{Safe Work Practices for Working with Wildlife}

By Tegwin Taylor and Danielle Buttke

Chapter 2 of

Section C, Techniques in Disease Surveillance and Investigation

Book 15, Field Manual of Wildlife Diseases

Edited by Katherine L.D. Richgels, Samantha E.J. Gibbs, and Margaret A. Wild

U.S. Geological Survey, U.S. Fish and Wildlife Service, and National Park Service

Techniques and Methods 15-C2 


\title{
U.S. Department of the Interior DAVID BERNHARDT, Secretary
}

\section{U.S. Geological Survey James F. Reilly II, Director}

\author{
U.S. Geological Survey, Reston, Virginia: 2020
}

For more information on the USGS - the Federal source for science about the Earth, its natural and living resources, natural hazards, and the environment-visit https://www.usgs.gov or call 1-888-ASK-USGS.

For an overview of USGS information products, including maps, imagery, and publications, visit https://store.usgs.gov.

Any use of trade, firm, or product names is for descriptive purposes only and does not imply endorsement by the U.S. Government.

Although this information product, for the most part, is in the public domain, it also may contain copyrighted materials as noted in the text. Permission to reproduce copyrighted items must be secured from the copyright owner.

Suggested citation:

Taylor, T., and Buttke, D., 2020, Safe work practices for working with wildlife: U.S. Geological Survey Techniques and Methods, book 15, chap. C2, 26 p., https://doi.org/10.3133/tm15C2.

ISSN 2328-7055 (online) 


\section{Contents}

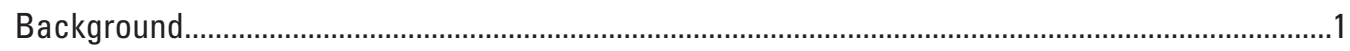

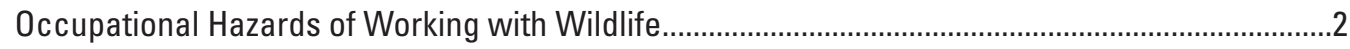

Environmental Hazards .....................................................................................................2

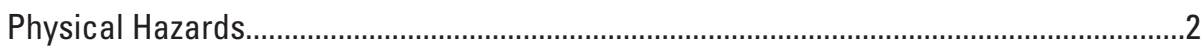

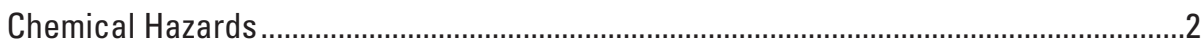

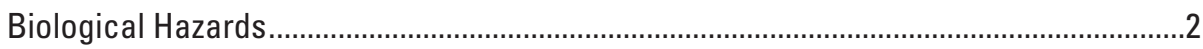

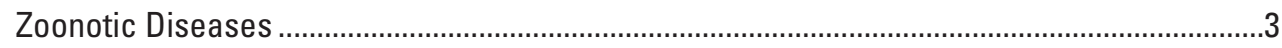

Mental Health and Workplace Stress ......................................................................................4

Best Practices for Working with Wildlife ........................................................................................

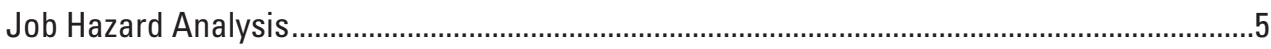

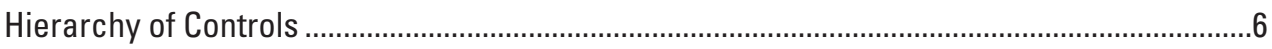

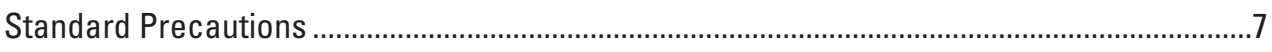

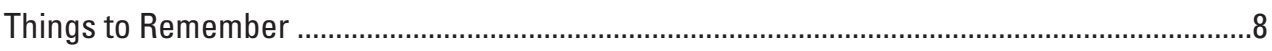

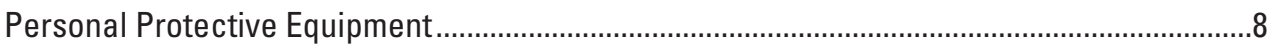

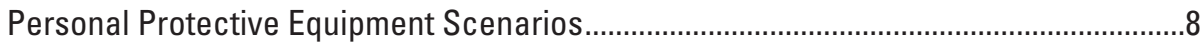

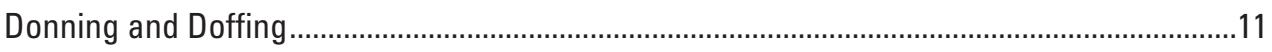

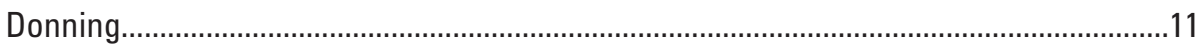

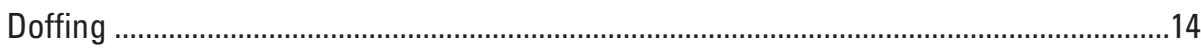

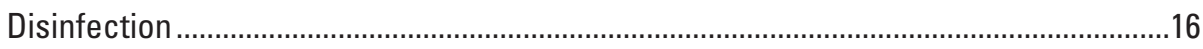

Workplace Safety and Health Program .................................................................................16

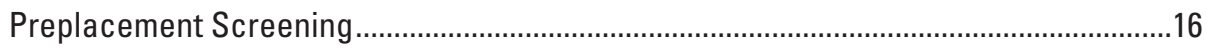

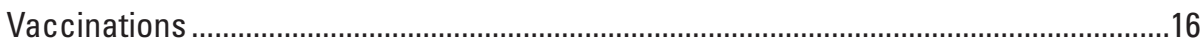

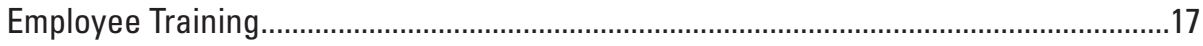

Medical Surveillance ...................................................................................................... 17

Workplace Assessments .................................................................................................17

Safety and Health Regulations for Wildlife Workers ......................................................................18

Bloodborne Pathogen Standard ................................................................................................ 18

Personal Protective Equipment Standard .............................................................................. 18

Respiratory Protection Standard ........................................................................................... 19

Hazard Communication Standard ........................................................................................... 19

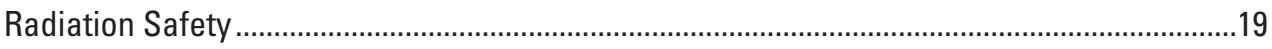

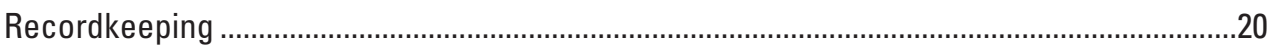

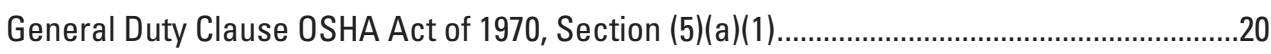

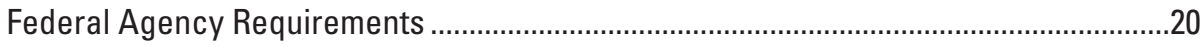

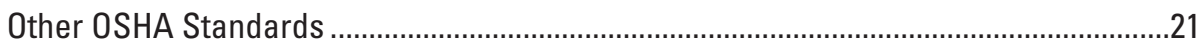

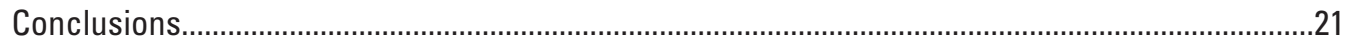

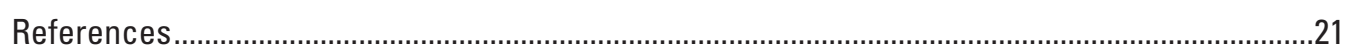

Appendix 1. Example of a Preplacement Medical Questionaire

Suitable for Modification ....................................................................................................23

Appendix 2. Examples of Quick Response or Medical Alert Cards ...........................................24 


\section{Tables}

1. Summary of the primary exposure routes, common activities, and zoonotic diseases of particular concern for wildlife workers.

2. Personal protective equipment to be used in the field depending on the

activity and level of risk... 


\title{
Safe Work Practices for Working with Wildlife
}

\author{
By Tegwin Taylor ${ }^{1}$ and Danielle Buttke ${ }^{1}$
}

\section{Background}

Most wildlife biologists, technicians, and veterinarians complete their tasks safely and uneventfully every day. However, some significant risks exist in this line of work, and injuries, illnesses, and accidental deaths among wildlife workers do occur. Aviation accidents (airplane and helicopter), drownings, and car and truck accidents are the most common causes of fatalities among wildlife workers (Sasse, 2003).

Although rare, serious zoonotic infections also happen. Being mindful of occupational hazards and zoonoses (diseases transmitted between humans and animals), and the various ways to minimize these risks, can help workers stay safe and healthy on the job.

Occupational safety and health concerns within the veterinary field, as well as resources to prevent and respond to these types of situations, have continued to emerge after significant events involving occupational exposures and risk identification. Although much of the guidance is directed toward veterinarians in clinical settings, it includes components that are relevant to wildlife veterinarians, technicians, biologists, and other workers who handle or work in environments with wildlife, collectively referred to as "wildlife workers" throughout this document.

The "Compendium of Veterinary Standard Precautions for Zoonotic Disease Prevention in Veterinary Personnel" was first published online by the National Association of Public Health Veterinarians in 2006. It serves as a primary resource for infection prevention and control within veterinary practices, specifically emphasizing prevention of zoonotic disease transmission. In 2013, the National Institute for Occupational Safety and Health (NIOSH) added veterinarians to the National Occupational Research Agenda. This designation includes wildlife workers in the healthcare and social assistance sectors, recognizing that these workers face unique risks that are comparable to and sometimes exceed those risks in human medicine (Centers for Disease Control and Prevention, 2013).

Studies and resources addressing zoonotic diseases specifically in wildlife workers were not available until after 2007. These studies and resources were made available because a National Park Service (NPS) wildlife biologist died

${ }^{1}$ U.S. National Park Service. from pneumonic plague after exposure to an infected mountain lion (Wong and others, 2009). Shortly after this death, the NPS took a series of steps to (1) assess wildlife biologists' perceptions and risks regarding zoonotic disease, (2) identify prevalence and incidence of zoonotic disease among wildlife biologists, and (3) develop and improve zoonotic disease prevention among wildlife workers. The recommendations and resources developed by the NPS as a result of this process have been adapted and incorporated into this chapter as we review the following:

- Occupational hazards of working with wildlife

- Environmental risks

- Physical hazards

- Chemical hazards

- Biological hazards

- Zoonotic disease hazards

- Mental health and workplace stress

- Best practices for working with wildlife

- Job hazard analyses

- Hierarchy of controls (HOCs)

- Standard precautions

- Personal protective equipment (PPE)

- PPE scenarios

- Donning and doffing

- Employee wellness program

- Preplacement screening

- Vaccinations

- Employee training

- Medical surveillance 
- Safety regulations for wildlife workers (from the Occupational Safety and Health Administration [OSHA])

- Bloodborne pathogens standard

- PPE standard

- Respiratory protection standard

- Radiation safety

- General duty clause

- Hazard Communication Standard

- Recordkeeping

\section{Occupational Hazards of Working with Wildlife}

Work involving direct contact with both live and dead wildlife presents unique risks and hazards that require specialized education and awareness to prevent harm. The following sections are not all inclusive but intended to focus on those risks unique to the wildlife work field.

\section{Environmental Hazards}

In one study of biologists and other wildlife workers, 100 percent of respondents reported working outside as part of their job duties (Bosch and others, 2013). Although working in nature has many health benefits, the outdoor environment poses a variety of hazards compared to the average desk job. Not only are dynamic weather conditions a concern, but field work often requires navigating difficult terrain while carrying cumbersome equipment, in addition to the inherent hazards of the task at hand. If workers are ill prepared, these conditions can pose a variety of risks for wildlife workers, including the following:

\section{Physical Hazards}

- Natural terrain/environment

- Being stung by an insect or attacked, bitten, kicked, or gored by an animal

- Dangers of working in or around water bodies*

- Temperature extremes
- Ergonomic challenges of working in the field

- Slips, trips, and falls

- Visual impairment at night or in poorly lit environments

- Sun exposure/ultraviolet radiation

- Man-made concerns

- Transportation hazards including airplanes, helicopters, trucks, and cars*

- Elevated noise exposures

- Firearms and remote delivery systems

- Handling scalpels and needles

- Workplace violence

*Aviation accidents (airplane and helicopter), drownings, and car and truck accidents are the most common causes of fatalities among wildlife workers (Sasse, 2003).

\section{Chemical Hazards}

Many wildlife workers are exposed to chemical hazards while working in the field or in the laboratory. If chemicals are not stored or handled properly, they have the potential to cause adverse health effects, and these effects depend on the route and duration of exposure. Specific information about the hazards of a chemical product can be found on the material safety data sheets provided by the manufacturer, importer, or distributer of the product. Some of the potential chemical hazards for wildlife workers include the following:

- Disinfectants

- Formalin

- Pharmaceuticals (for example, anesthetics, antibiotics)

\section{Biological Hazards}

Many biological hazards pose risks to wildlife workers:

- Harmful algal blooms and other waterborne exposures and diseases

- Toxic plants

- Venomous animals and insects

- Zoonotic disease 


\section{Zoonotic Diseases}

Given their frequent exposure to wildlife and arthropods in the field, wildlife workers may be at increased risk of acquiring zoonotic infections: diseases that are transmitted between animals and people (Adjemian and others, 2012). Some serious zoonotic diseases that are commonly associated with wildlife include hantaviruses, plague, rabies, and tularemia. Depending on location, vector-borne diseases, such as anaplasmosis, erhlichiosis, Lyme disease, tickborne relapsing fever, and various arboviruses are of considerable concern as well.

In a study that assessed zoonotic disease exposures in NPS employees of two prominent national parks, more than 75 percent of 141 participants had evidence of prior infection with one or more zoonotic diseases. Bartonella henselae, spotted fever group rickettsiae, and Toxoplasma gondii were the most frequently detected diseases; evidence of exposure to rare and serious diseases, such as anthrax and Q fever, was also noted (Adjemian and others, 2012). Additionally, more than 15 percent of the study population developed a new zoonotic infection during the 1-year period of the study. Study participants also had prior exposure to several mosquito- and tick-borne pathogens, Baylisascaris, Brucella spp., and Leptospira spp.

Primary exposure routes, common activities, and zoonotic diseases of particular concern for wildlife workers are summarized in table 1:
Risk factors for zoonoses that have been identified in wildlife workers include the following (Adjemian and others, 2012):

- Working outside

- Insect bites

- Contact with the following materials

- Deceased canids

- Fish tissue/fluids

- Reptiles and reptile feces

- Rodents and rodent urine/feces

Being aware of the potential zoonotic diseases in the area where field work is taking place and implementing appropriate protective measures are important factors in limiting disease exposures. For example, although there have been deaths of wildlife workers attributed to hantaviruses, the risk for infection with hantaviruses is generally low among biologists that frequently handle rodents (Hafner, 2007). However, exposure to peridomestic rodent habitat, such as cabins and other buildings, has been cited as a likely source of hantavirus infection (de St. Maurice, 2017). More specific approaches to limiting exposure to vector-borne and other zoonotic diseases will be covered in the best practices section of this chapter.

Table 1. Summary of the primary exposure routes, common activities, and zoonotic diseases of particular concern for wildlife workers.

[Table adapted from the National Park Service's Safe Work Practices for Employees Handling Wildlife (National Park Service, 2008)]

\begin{tabular}{|c|c|c|c|}
\hline $\begin{array}{l}\text { Transmission } \\
\text { route }\end{array}$ & Entry into body & Risk-activity examples & Disease examples \\
\hline Contact-direct & $\begin{array}{l}\text { Ingestion, } \\
\text { mucous membrane contamination, } \\
\text { breaks in the skin }\end{array}$ & $\begin{array}{l}\text { Trapping, handling, and sampling live or } \\
\text { dead animals. Handling animal samples } \\
\text { (for example, blood) }\end{array}$ & $\begin{array}{l}\text { Anthrax, brucellosis, } \\
\text { plague, rabies, } \\
\text { Salmonella spp, } \\
\text { scabies, tularemia, } \\
\text { avian influenza. }\end{array}$ \\
\hline Aerosol & $\begin{array}{l}\text { Inhaled particles or droplets deposited } \\
\text { on mucous membranes }\end{array}$ & $\begin{array}{l}\text { Disturbing contaminated dust particles } \\
\text { (for example, cleaning buildings) and } \\
\text { close contact with infected animals }\end{array}$ & $\begin{array}{l}\text { Inhaled particles: } \\
\text { hantaviruses, } \\
\text { highly pathogenic avian } \\
\text { influenza. } \\
\text { Droplet: plague. }\end{array}$ \\
\hline
\end{tabular}


Because wildlife workers can be exposed to many zoonotic diseases, and because zoonoses vary so much by geographic area, individual diseases are not described here. A thorough summary of zoonoses of importance in the United States is provided by the National Association of State Public Health Veterinarians as appendix 1 of the "Compendium of Veterinary Standard Precautions for Zoonotic Disease Prevention in Veterinary Personnel" (Williams, 2015), available at: http://nasphv.org/Documents/VeterinaryStandardPrecautions. pdf.

More thorough summaries of zoonotic diseases are provided on the Center for Food Security and Public Health website, available at http://www.cfsph.iastate.edu/Zoonoses/ index.php.

\section{Mental Health and Workplace Stress}

Mental health and workplace stress are frequent challenges many veterinarians and wildlife workers face. Several studies done in various countries have identified veterinarians as being at higher risk of suicide compared to other professions and the general public. In a 2015 study of more than 11,000 veterinarians, 19 percent were currently experiencing psychological distress, yet most of those individuals were not currently receiving mental health treatment (Nett, 2015). Whether it is because an individual is struggling with his or her own personal issues, or an employee or colleague is responding to specific incidents within the workplace, according to Nett (2015) wildlife workers should be aware of mental illness and suicide for the following reasons:

- Occupational stress has been associated with depression, and major depression is an established risk factor for suicide.

- Anxiety, compassion fatigue, and depression are often affiliated with animal shelters and wildlife rescue organizations.

- Veterinarians experiencing psychological distress are less likely to receive treatment than the general public.

- Many veterinarians and wildlife workers have access to and are knowledgeable about potent anesthetic drugs, euthanasia solution, and firearms.

- Many individuals seek out remote places in nature, such as national parks, to commit suicide.

- Veterinarians perceive greater stigma for mental illness and have a higher prevalence of depression and suicide ideation compared to the general public.
Some helpful guidance regarding how to respond to a struggling colleague is summarized in Stoewen, 2015:

- Approach the person and ask how they are feeling.

- Listen carefully.

- Ask if your colleague is having suicidal thoughts, and if they are have them call a crisis hotline; if they refuse, call for guidance yourself.

- Assure the person that things will change.

- Stay with them until you know they are safe.

- Make plans to see them again.

However unpleasant or uncomfortable, it is important for wildlife workers to be cognizant of these tendencies within the veterinary and related fields and look for warning signs of trouble among colleagues. Suicide prevention resources for veterinarians can be found here:

- American Veterinary Medical Association

- "Wellbeing," available at https://www.avma.org/ resources-tools/wellbeing.

- Canadian Veterinary Journal

- "Veterinary Wellness-Suicide in Veterinary Medicine-Let's Talk About It," available at https://www. ncbi.nlm.nih.gov/pmc/articles/PMC4266064/pdf/ cvj_01_89.pdf.

- Vetlife

- "Vetlife Helpline," available at https://www.vetlife. org.uk/how-we-help/vetlife-helpline/. 


\section{Best Practices for Working with Wildlife}

To prevent exposure to zoonotic diseases and other hazards, and to minimize the chance of accidents or injuries in the field, wildlife workers can incorporate a few best practices into their jobs. In the following sections, the current best practices of using job hazard analysis, HOCs, standard precautions, personal protective equipment, and workplace safety and health programs to minimize or mitigate risks for wildlife workers are described.

\section{Job Hazard Analysis}

Understanding the hazards associated with a job is helpful for planning work and avoiding mishaps. To accomplish this, a job hazard analysis (JHA) can be completed. Although each organization and agency may have more specific guidelines for employees, according to the Occupational Safety and Health Administration (OSHA) the primary components of a JHA include the following:

- Organize the job into tasks:

- Ask the questions who, what, when, where, how, and why.

- List each task in order.

- Avoid making each task too general or specific.

- Consider observing or recording the task being completed.

- Review steps to ensure nothing was missed.

- Identify and evaluate potential hazards for each task:

- What could go wrong?

- What are the consequences?

- How likely is a hazard to happen?

- What other factors contribute to the hazard?

- Establish procedures to minimize or eliminate the hazard(s) of the specific job or task, for example:

- Do not drive in extreme weather conditions.

- Avoid working in remote areas alone.

- Be aware of needles and scalpels when in use.

- Wear PPE appropriate for the task.
It is important to review JHAs regularly and revise them when job duties change or when an incident happens. JHAs are often recommended for high-risk jobs, such as those that cause a high rate of injury, have the potential for severe or disabling injuries, or those in which one simple error could have severe consequences. Successful JHAs are specific to each job and avoid the "one size fits all" approach. The benefits of completing JHAs include preventing and eliminating hazards, reducing injuries and illnesses, lowering workers' compensation costs, and increasing productivity.

More information on JHAs is available here:

- OSHA's "Job Hazard Analysis" booklet, available at https://www.osha.gov/Publications/osha3071.pdf.

- Safety and Health Magazine's "Job Hazard Analysis/ Job Safety Analysis," available at http://www.safetyandhealthmagazine.com/articles/14386-job-hazardanalysis. 


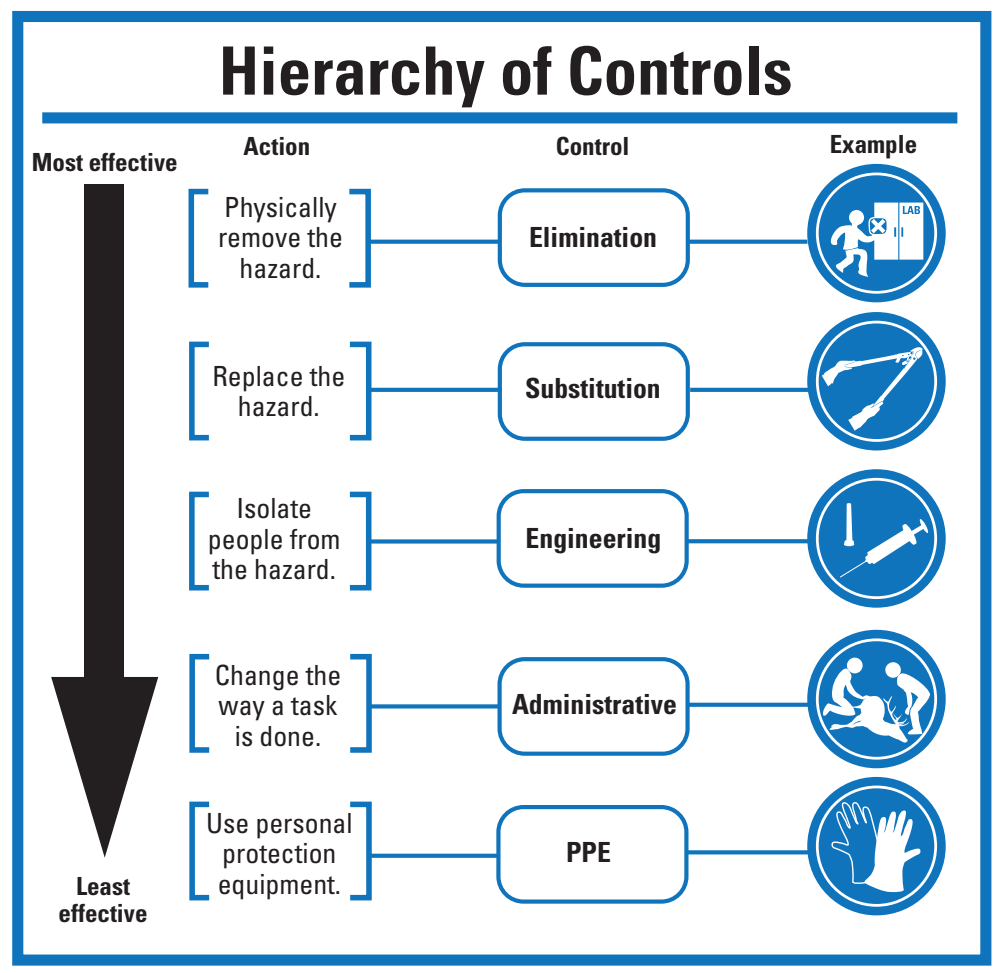

Image source: S. Sparhawk, National Park Service

\section{Hierarchy of Controls}

It is helpful to consider the hierarchy of controls (HOCs) and establish procedures to eliminate hazards when completing JHAs. Controls are typically placed at the source of the hazard, where the hazard travels, or with the worker. According to OSHA (2016), the HOCs helps an employee to minimize exposure to a hazard through a series of steps, following a gradient from most to least effective:

- Elimination removes the hazard from the workplace:

- Submit a suspicious animal carcass to a diagnostic laboratory for necropsy instead of completing a necropsy in the field.

- Obtain archived samples instead of live trapping and anesthesia to obtain genetic information on select study species.

- Substitution replaces the hazard with something less hazardous:

- Use a lopper (or tree trimmer) instead of an open blade or saw to cut through tissue during a necropsy.

- Use chemical restraint instead of physical restraint.
- Engineering controls modify equipment or revise the process to reduce exposure to the hazard:

- Use self-recapping needles for blood draws instead of standard needles that require manual recapping.

- Use a jabstick or remote delivery system instead of hand injection in a wild animal.

- Administrative controls (also called work practice controls) change the way a task is done to reduce exposure to the hazard:

- Instead of working alone, have another person present to assist and stay vigilant for other hazards while completing a field necropsy.

- PPE controls include the use of appropriate equipment to prevent exposures to hazards:

- Don gloves and coveralls when inspecting/collecting an animal for necropsy.

More information on the HOCs is available at https://www. cdc.gov/niosh/topics/hierarchy/. 


\section{Standard Precautions}

Standard precautions are a set of infection control practices put in place to prevent transmission of infectious diseases through blood or bodily fluids (Centers for Disease Control and Prevention, 2016). Standard (or universal) precautions typically refer to the basic measures needed to prevent human to human transmission. The implementation of standard precautions by the veterinary field has been more recent but is now considered a best practice in the clinic setting. Although the environment and tasks for wildlife workers vary considerably from a clinic setting, standard precautions should be implemented in the field as well. Those measures include the following:

- Use protective barriers such as gloves.

- Do not eat, drink, or smoke when working around wildlife.

- Wash hands with soap and water (whenever soap and water are available) for at least 15 seconds. If soap and water are not available, use an alcohol-based hand rub with at least 60 percent alcohol. Always implement hand hygiene after removing PPE, whenever hands are visibly soiled, and before eating or drinking. If hands are visibly soiled, soap and water are more effective than alcohol-based hand rub.

- Take precautions to prevent bites, scratches, and needle sticks or other injuries.

- Work in well-ventilated areas when indoors, and upwind of animals or specimens when working outdoors.

- Transport carcasses and store tissue samples properly.

- Disinfect soiled equipment and contaminated environmental surfaces.

- Seek medical attention when ill and inform provider of potential disease exposures.
Of course, some situations will call for additional precautions. Leading a JHA and taking the HOCs into consideration for a particular task will help determine which additional measures should be incorporated. Assessing the potential routes of exposure and identifying appropriate prevention measures for a particular task will also be helpful. Examples include the following (National Park Service, 2008):

- To minimize direct contact exposure, use barrier protections such as gloves and coveralls.

- To minimize indirect contact exposure, disinfect equipment and environmental surfaces and practice good hand hygiene.

- To minimize aerosol exposure, work outdoors when possible and upwind of the potential risk and don an appropriate respirator for the disease of concern.

- To minimize vector-borne exposure, wear diethyltoluamide (commonly known as DEET) or other U.S. Environmental Protection Agency-registered repellents, pants, and long sleeves.

Respirators should be used in the context of a comprehensive respiratory protection program that meets the requirements of OSHA's Respiratory Protection Standard (Occupational Safety and Health Administration, 2006). Respiratory protection programs must include proper fit testing, medical exams, and worker training. Employers must select NIOSH-approved respirators that are appropriate to protect workers from the hazard, including aersolized infectious material. At a minimum, use an N95 or better filtering facepiece respirator when an aerosol hazard is present. Although half- or fullface air-purifying respirators with appropriate particulate (or particulate/chemical combination cartridges, if needed) may be suitable, as well; workers may find that powered air-purifying respirators may provide additional comfort (in addition to higher levels of respiratory protection), especially in hot environments. Please note: washing your hands is one of the best ways to prevent disease transmission. 


\section{Things to Remember:}

- Be familiar with diseases found in your area and their symptoms.

- Inform natural resources managers of sick or dead animals.

- Be familiar with warning signs for unusual mortality events:

- Multiple dead animals

- Blood coming from orifices (nose, rectum) without signs of trauma

- Animals displaying neurologic signs prior to death.
- Know how to properly handle, store, and ship specimens.

- Ensure you have contact information for everyone who may have had contact with the animal so they can be contacted should a zoonotic disease be identified in the animal.

- Learn about the site prior to visiting to become aware of potential risks. This can protect both your and wildlife health.

\section{Personal Protective Equipment}

Two focus groups were held with NPS wildlife biologists and technicians in 2008 (Bosch and others, 2010). Individuals were interviewed regarding zoonotic disease exposures and risk perceptions, PPE use, and barriers to and facilitators of using PPE. Despite a recent death of an NPS employee from plague, concerns regarding zoonotic disease risk were low overall. Although many survey participants had access to N95 respirators, none had been fit tested or trained in their appropriate use. Several barriers to PPE use were identified:

- The work culture at individual parks

- Challenges of field environments

- The inconvenience of PPE use

- The lack of concern regarding zoonotic diseases, including the perception that consistent work practices (such as working at a slow pace) reduced the need for PPE.

Simply having PPE available and accessible was the most frequently mentioned facilitator for use of PPE. Based on these findings, the NPS developed "Safe Practices for Employees Handling Wildlife" (National Park Service, 2008) and "Safe Practices to Avoid Zoonotic Disease from Wildlife," (National Park Service, 2014) as quick reference guides. The quick reference guides and PPE kits were provided to NPS regional safety managers and any park that requested the materials.
In another survey of international wildlife workers, respondents reported taking extra precautions when working around sick animals (Garland-Lewis and others, 2017). These precautions included layering of gloves and use of N95 respirators and face shields. However, respondents also cited that access to PPE was difficult and impractical in challenging field settings (Garland-Lewis and others, 2017).

\section{Personal Protective Equipment Scenarios}

Although the NPS developed the following guidance ("Donning and Doffing" section), much of the content is applicable to wildlife workers in other agencies and organizations. Therefore, the presented information has been adapted and included here. The following table (table 2) provides a summary of appropriate PPE and practices to be used in the field, depending on the activity. The activities and recommended PPE are color coded from green (low risk) to red (high risk). Risk-based scenarios are helpful if the risk is known; if the risk is unknown, a higher level of protection should be selected. The highest level of protection should be the default unless a lower level can be justified. Consult wildlife health and zoonotic disease specialists to assist with PPE selection. 
Table 2. Personal protective equipment to be used in the field depending on the activity and level of risk.

[Table adapted from National Park Service's Safe Practices to Avoid Zoonotic Disease from Wildlife—Quick Reference Guide (National Park Service, 2014)]

\begin{tabular}{|c|c|c|c|c|c|}
\hline & & $\begin{array}{l}\text { Level of risk from green } \\
\text { (low) to red (high) }\end{array}$ & $\begin{array}{l}\text { nd (or) } \\
\text { s }\end{array}$ & $\begin{array}{l}\text { Respiratory protection } \\
\text { as appropriate to the } \\
\text { level of risk }\end{array}$ & $\begin{array}{l}\text { s that can be } \\
\text { fected }\end{array}$ \\
\hline & Activity & Condition & Personal protective equipment & Safe work practice & Route(s) of exposure \\
\hline 1 & $\begin{array}{l}\text { Handling apparently } \\
\text { healthy live animals. }\end{array}$ & $\begin{array}{l}\text { No substantial local } \\
\text { zoonotic disease } \\
\text { concerns or vectors; } \\
\text { risk from casual contact } \\
\text { is minimal. }\end{array}$ & & Does not apply & Contact, vector. \\
\hline 2 & $\begin{array}{l}\text { Handling biological } \\
\text { samples from } \\
\text { apparently healthy live } \\
\text { animals. }\end{array}$ & $\begin{array}{l}\text { No substantial local } \\
\text { zoonotic disease } \\
\text { concerns or vectors. }\end{array}$ & & Does not apply & $\begin{array}{l}\text { Contact with body fluids } \\
\text { or biological samples } \\
\text { may increase risk. } \\
\text { Contact, vector. }\end{array}$ \\
\hline 3 & $\begin{array}{l}\text { Collection of biological } \\
\text { samples (feces, urine, } \\
\text { fetuses) from the } \\
\text { environment for } \\
\text { management or } \\
\text { research where no } \\
\text { known zoonotic enzo- } \\
\text { otic disease occurs. }\end{array}$ & $\begin{array}{l}\text { Risk exists from contact } \\
\text { with body fluids and } \\
\text { tissues, but no known } \\
\text { disease risk is present. }\end{array}$ & $\begin{array}{l}\text { If splashes } \\
\text { may occur: }\end{array}$ & $\begin{array}{l}\text { - Store samples in approved and dedicated specimen storage location } \\
\text { according to protocols. }\end{array}$ & Contact, vector. \\
\hline 4 & $\begin{array}{l}\text { Handling for disposal } \\
\text { or submission of single } \\
\text { animal found dead } \\
\text { in area with no } \\
\text { substantial local } \\
\text { zoonotic disease or } \\
\text { vectors. }\end{array}$ & $\begin{array}{l}\text { Risk is minimal if } \\
\text { barrier is used. Risk may } \\
\text { increase with size of the } \\
\text { animal handled because } \\
\text { of increased chance of } \\
\text { contamination. }\end{array}$ & $\left\{\begin{array}{c}\text { Small } \\
\text { animal } \\
\text { Large } \\
\text { animal }\end{array}\right\}$ & $\begin{array}{l}\text { - Use appropriate precautions for transmission routes of diseases of } \\
\text { concern. } \\
\text { - Transport outside passenger area of vehicle (that is, truck bed or trunk). } \\
\text { - BNAag carcass tightly if it must be placed in passenger compartment } \\
\text { or to avoid leakage of body fluids into the environment. } \\
\text { - Cover all carcasses. }\end{array}$ & Contact, vector. \\
\hline 5 & $\begin{array}{l}\text { Handling multiple } \\
\text { animals found dead for } \\
\text { disposal or submission } \\
\text { in an area without } \\
\text { substantial zoonotic } \\
\text { disease risk or han- } \\
\text { dling single animal or } \\
\text { multiple animals in an } \\
\text { area with substantial } \\
\text { zoonotic disease risk. }\end{array}$ & $\begin{array}{l}\text { Risk may differ if the } \\
\text { mortality event is } \\
\text { recurring (for example, } \\
\text { juvenile birds washed } \\
\text { ashore) as opposed to } \\
\text { unexpected. }\end{array}$ & $\begin{array}{l}\text { Large } \\
\text { animal }\end{array}$ & $\begin{array}{l}\text { Follow work practices in number } 4 \text {. In addition: } \\
\text { - Inform colleagues and consult with wildlife disease professional for } \\
\text { potential causes of illness. } \\
\text { - In an unexpected mortality event: submit 1-5 animals for diagnostic } \\
\text { evaluation and dispose of remaining carcasses in landfill or other } \\
\text { approved means. } \\
\text { - Store samples in approved locations. } \\
\text { - Become familiar with disease symptoms in humans and seek medical } \\
\text { attention if symptoms occur (inform health care provider of occupation } \\
\text { and potential exposure). }\end{array}$ & $\begin{array}{l}\text { Contact, vector. } \\
\text { Aerosol in rare } \\
\text { circumstances. }\end{array}$ \\
\hline 6 & $\begin{array}{l}\text { Briefly handling or } \\
\text { contacting live or } \\
\text { dead animals } \\
\text { incidental to other } \\
\text { work assignments. }\end{array}$ & $\begin{array}{l}\text { Incidental exposure as a } \\
\text { result of other indoor or } \\
\text { outdoor duties. }\end{array}$ & $\begin{array}{l}\text { (Gloves or } \\
\text { inverted bag) }\end{array}$ & $\begin{array}{l}\text { - Inform colleagues as appropriate. } \\
\text { - Transport outside passenger area of vehicle (that is, truck bed or trunk). } \\
\text { Bag carcass tightly if it must be placed in passenger compartment to } \\
\text { - Cover leakage of body carcasses. }\end{array}$ & Contact, vector. \\
\hline 7 & $\begin{array}{l}\text { Handling apparently } \\
\text { healthy live animals } \\
\text { (or samples) from areas } \\
\text { with known zoonotic } \\
\text { disease risks. }\end{array}$ & $\begin{array}{l}\text { Disease exists in } \\
\text { (or spills into) handled } \\
\text { species or associated } \\
\text { vectors (for example, } \\
\text { plague, rabies, } \\
\text { brucellosis). }\end{array}$ & & $\begin{array}{l}\text { - Use appropriate precautions for transmission routes of diseases of } \\
\text { concern. } \\
\text { - Become familiar with symptoms of the disease in humans and seek } \\
\text { medical attention if symptoms occur (inform health care provider of } \\
\text { occupation and potential exposure). }\end{array}$ & $\begin{array}{l}\text { Contact, vector. } \\
\text { Aerosol. }\end{array}$ \\
\hline 8 & $\begin{array}{l}\text { Handling sick or } \\
\text { injured live animals for } \\
\text { euthanasia, sampling, } \\
\text { or transportation. }\end{array}$ & $\begin{array}{l}\text { Risk increases because } \\
\text { animal movement } \\
\text { may increase contact; } \\
\text { illness may be zoonotic } \\
\text { and increase sources } \\
\text { of contaminants (for } \\
\text { example, diarrhea). }\end{array}$ & $\begin{array}{l}\text { s appropriate } \\
\text { disease: }\end{array}$ & $\begin{array}{l}\text { - Use appropriate precautions for transmission routes of diseases of } \\
\text { concern. } \\
\text { - Submit diagnostic samples from sick animals. }\end{array}$ & $\begin{array}{l}\text { Contact, vector. } \\
\text { Aerosol. }\end{array}$ \\
\hline 9 & $\begin{array}{l}\text { Handling healthy } \\
\text { appearing animal col- } \\
\text { lected for management/ } \\
\text { research or found dead } \\
\text { with no known zoo- } \\
\text { notic disease risk for } \\
\text { necropsy, dissection, } \\
\text { or food processing. }\end{array}$ & $\begin{array}{l}\text { Risk is increased } \\
\text { because of closer } \\
\text { contact with body } \\
\text { fluids and tissues, but } \\
\text { no reason to suspect } \\
\text { high-risk zoonotic } \\
\text { pathogens. }\end{array}$ & $\begin{array}{l}\text { If performing necropsy, } \\
\text { dissection, or food } \\
\text { processing: }\end{array}$ & $\begin{array}{l}\text { - If an animal has received any drugs (anesthetics, euthanasia agent), } \\
\text { it is unfit for human consumption and must be removed or withheld } \\
\text { from the human food chain. }\end{array}$ & $\begin{array}{l}\text { Contact, vector. } \\
\text { Aerosol. }\end{array}$ \\
\hline 10 & $\begin{array}{l}\text { Collection of } \\
\text { biological samples } \\
\text { (feces, urine, fetuses) } \\
\text { from the environment } \\
\text { for management or } \\
\text { research where } \\
\text { zoonotic disease } \\
\text { vectors occur. }\end{array}$ & $\begin{array}{l}\text { Risk from contact } \\
\text { with body fluids and } \\
\text { tissues from potentially } \\
\text { infected animals or their } \\
\text { parasites }\end{array}$ & $\begin{array}{l}\text { As appropriate } \\
\text { to disease: }\end{array}$ & $\begin{array}{l}\text { - Use appropriate precautions for transmission routes of diseases of } \\
\text { concern. } \\
\text { In addition: } \\
\text { - Inform colleagues and consult with a wildlife disease professional for } \\
\text { potential causes of illness. } \\
\text { - Become familiar with disease symptoms in humans and seek medical } \\
\text { attention if symptoms occur (inform health care provider of occupation } \\
\text { and potential exposure). }\end{array}$ & $\begin{array}{l}\text { Contact, vector. } \\
\text { Aerosol. }\end{array}$ \\
\hline 11 & $\begin{array}{l}\text { Handling dead animal } \\
\text { that was observed ill or } \\
\text { a species with known } \\
\text { zoonotic disease risk } \\
\text { (for example, prairie } \\
\text { dog, ground squirrel) } \\
\text { for necropsy or } \\
\text { dissection. }\end{array}$ & $\begin{array}{l}\text { Risk is increased } \\
\text { because of closer } \\
\text { contact with body fluids } \\
\text { and tissues and } \\
\text { unknown cause of } \\
\text { death. }\end{array}$ & & $\begin{array}{l}\text { - Inform colleagues and consult with wildlife health disease profes- } \\
\text { sional for potential causes of illness. } \\
\text { - Become familiar with disease symptoms in humans and seek medical } \\
\text { attention if symptoms happen (inform health care provider of occupa- } \\
\text { tion and potential exposure). } \\
\text { - Become familiar with warning signs for unusual mortality events: mul- } \\
\text { tiple dead animals, blood coming from orifices (nose, rectum) without } \\
\text { signs of trauma, animals displaying neurologic signs before death. }\end{array}$ & $\begin{array}{l}\text { Contact, vector. } \\
\text { Aerosol. }\end{array}$ \\
\hline 12 & $\begin{array}{l}\text { Cleaning areas of } \\
\text { animal excreta and } \\
\text { handling rodents in } \\
\text { traps in indoor or } \\
\text { field locations with } \\
\text { significant } \\
\text { accumulation of } \\
\text { organic matter. }\end{array}$ & $\begin{array}{l}\text { Large quantities of } \\
\text { mouse excreta or bird } \\
\text { or bat guano are of } \\
\text { considerable concern, } \\
\text { especially in an indoor } \\
\text { setting. }\end{array}$ & F) & $\begin{array}{l}\text { See precautions for workers frequently exposed to rodents in } \\
\text { "Hantavirus Pulmonary Syndrome-United States—Updated } \\
\text { Recommendations for Risk Reduction." Available at: } \\
\text { https://wwww.cdc.gov/mmwr/preview/mmwrhtml/rr5109a1.htm. }\end{array}$ & $\begin{array}{l}\text { Contact, vector. } \\
\text { Aerosol. }\end{array}$ \\
\hline
\end{tabular}




\section{Donning and Doffing}

Donning and doffing is the process for appropriately putting on (donning) and taking off (doffing) PPE (National Park Service, 2008). Before beginning an activity, it is helpful to consider the following steps:

- Define "contaminated" (higher risk) and "clean" (lower risk) areas and a "decontamination" area as needed.

- Assemble all disposal materials and disinfection equipment and products.

- Inspect all PPE to ensure it is in working order and not damaged.

\section{Donning}

1 If using eye protection and respirator, put these on first. Ensure the respirator has an appropriate seal to face by using two hands to pull the respirator away from the face to check for negative pressure.

Please note that anyone using a respirator must be fit-tested before use, medically cleared, and clean shaven where the respirator seals to face, as required per OSHA standards.
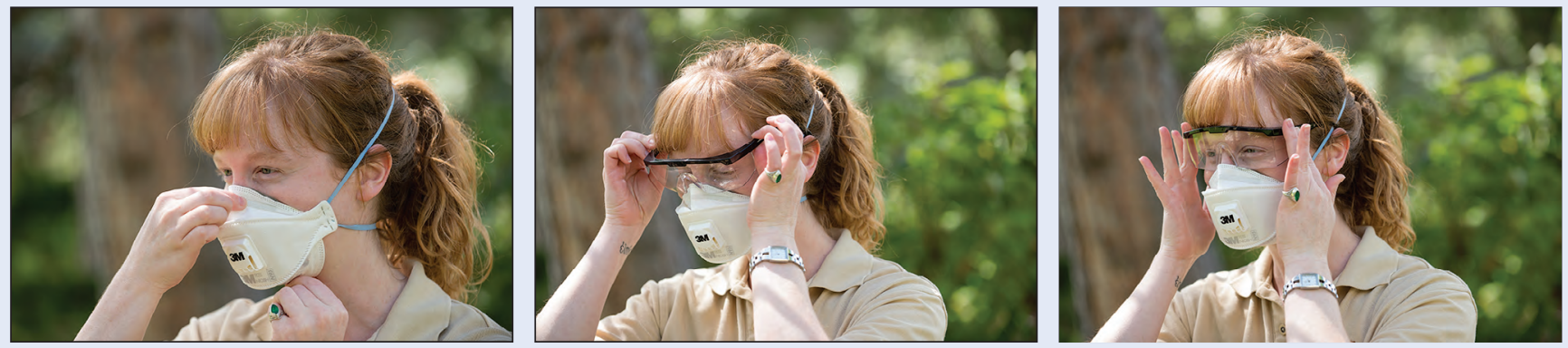

2 Put on the coveralls and ensure no holes are present. If coveralls have a hood, pull the hood over the respirator and goggles.
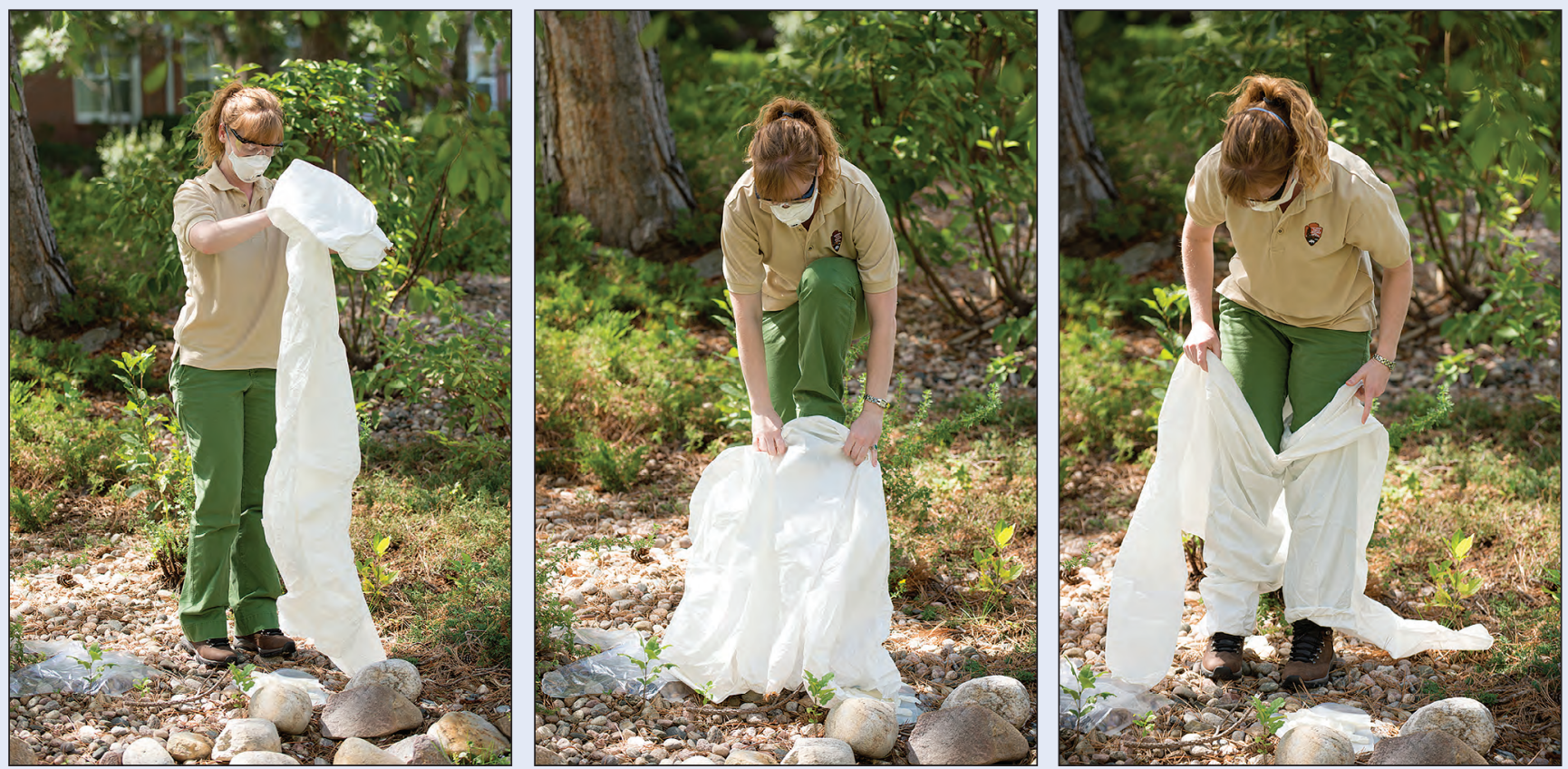
Donning continued 2 Put on the coveralls and ensure no holes are present. If coveralls have a hood, pull the hood over the respirator
and goggles.
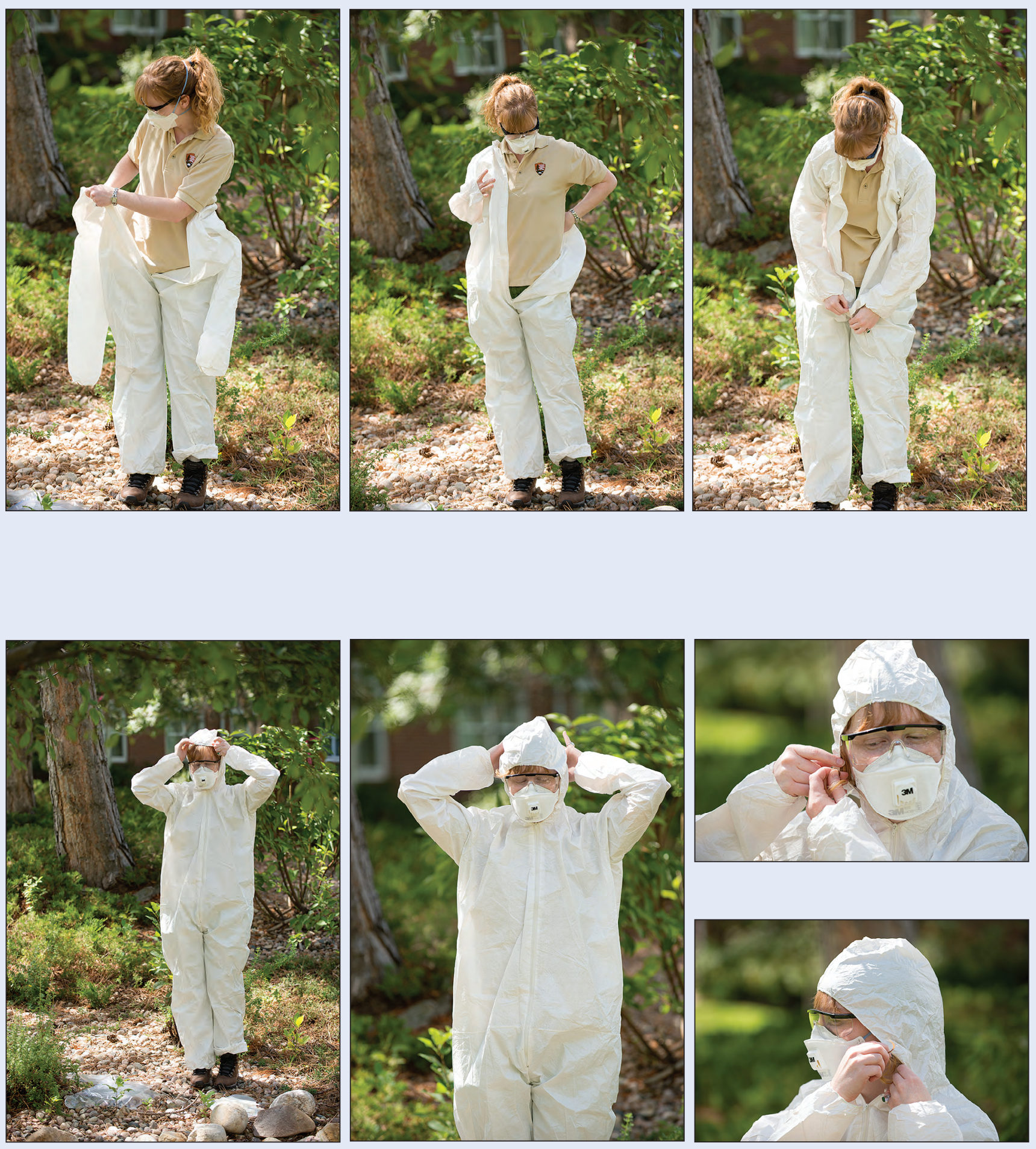


\section{Donning}

continued

3 Pull on the boots or boot covers, pulling the coveralls over the boots or boot covers. Tape coveralls to boots or boot covers if concerned about arthropod exposures.
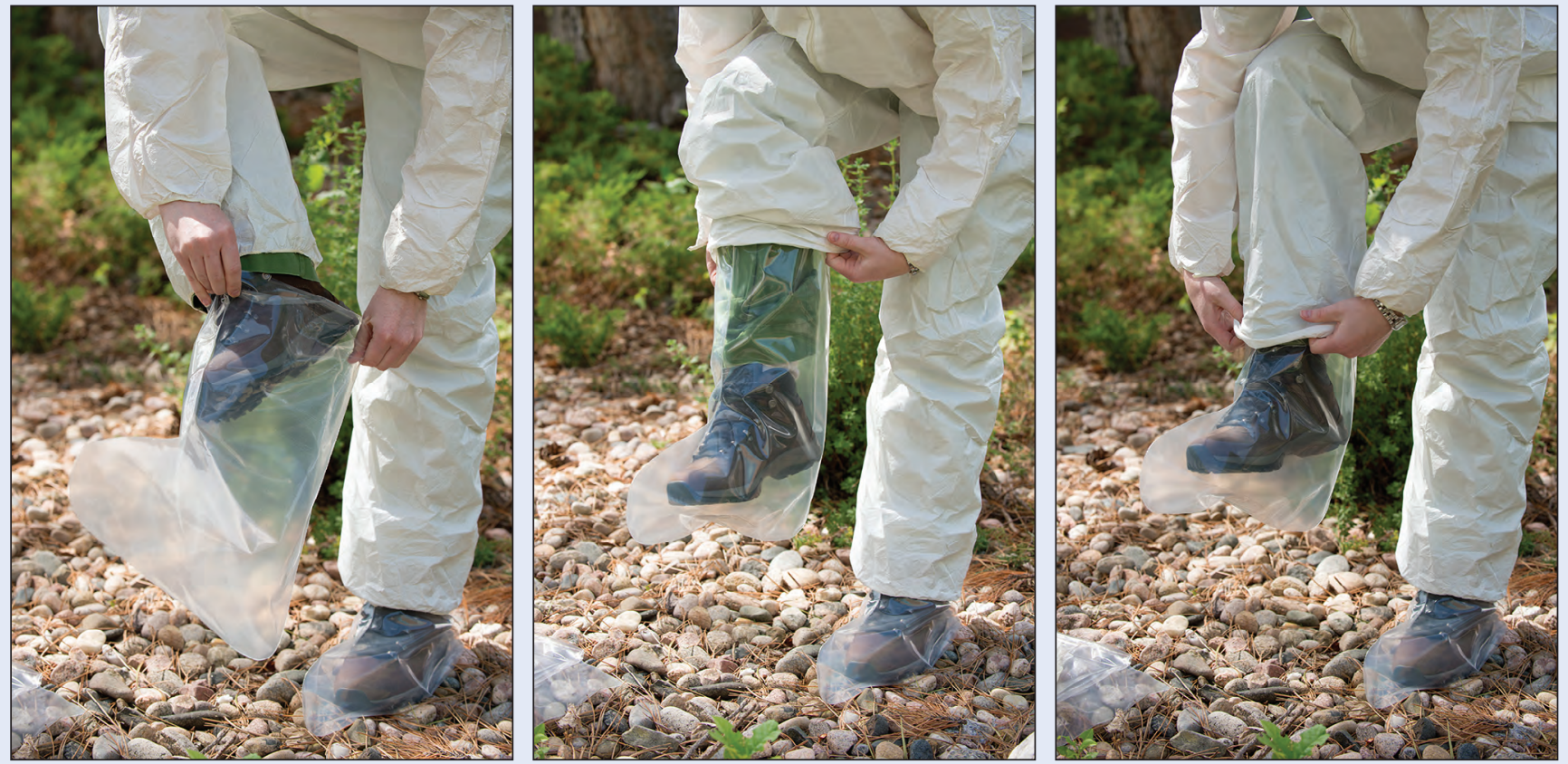

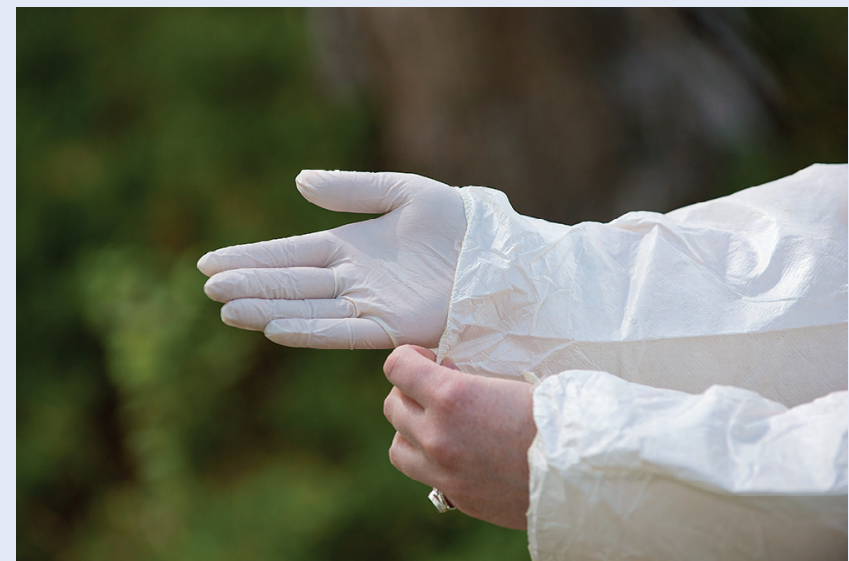

Pull coverall cuff over first layer of gloves.

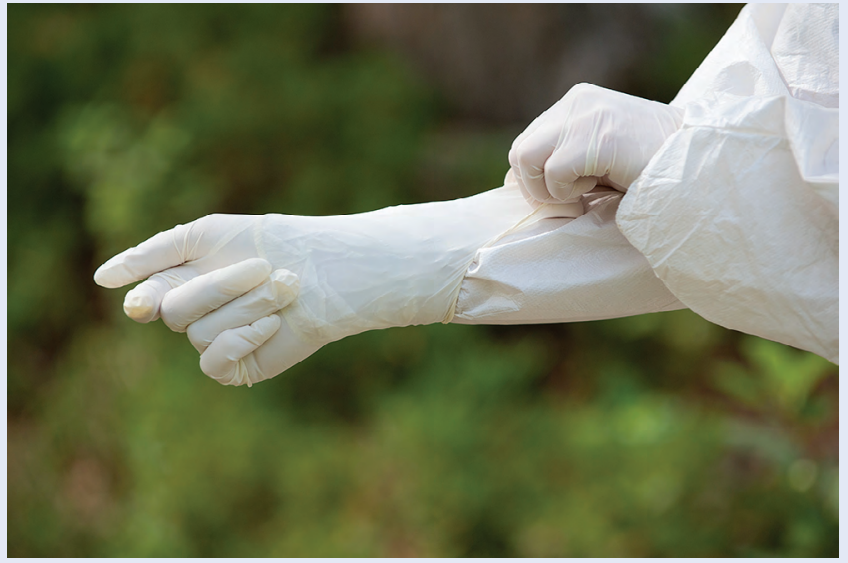

If a second layer of gloves is being used, pull them over the coverall sleeve.

4 Pull on the gloves and pull coverall cuffs over the gloves. If using a second layer of gloves, the second layer of gloves can be pulled over the coveralls; tape coveralls to the gloves if concerned about arthropod exposures. 
Doffing After completing the activity, move to the decontamination area.

1 Remove the coveralls: unzip from the front, pull from the shoulders and roll down toward the ankles; roll the coveralls down over the outside of the boot covers; and remove the outer layer of the gloves with coveralls, leaving the inner layer of gloves on.
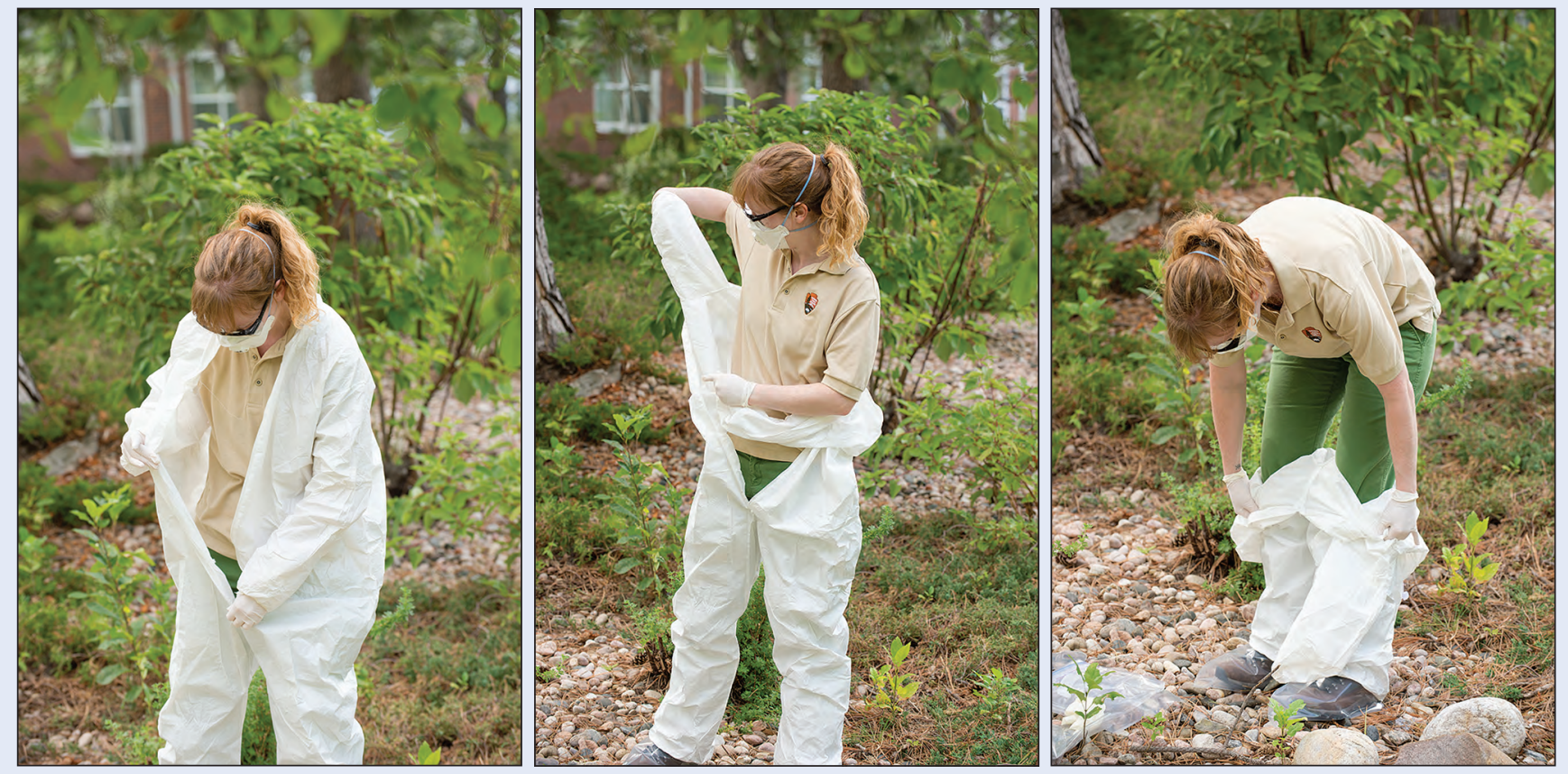

2 Step out of the boots or boot covers into the clean zone. If you are wearing reusable boots without the covers, disinfect the boots before stepping into the clean zone. Place the coveralls and boot covers in a disposable bag.
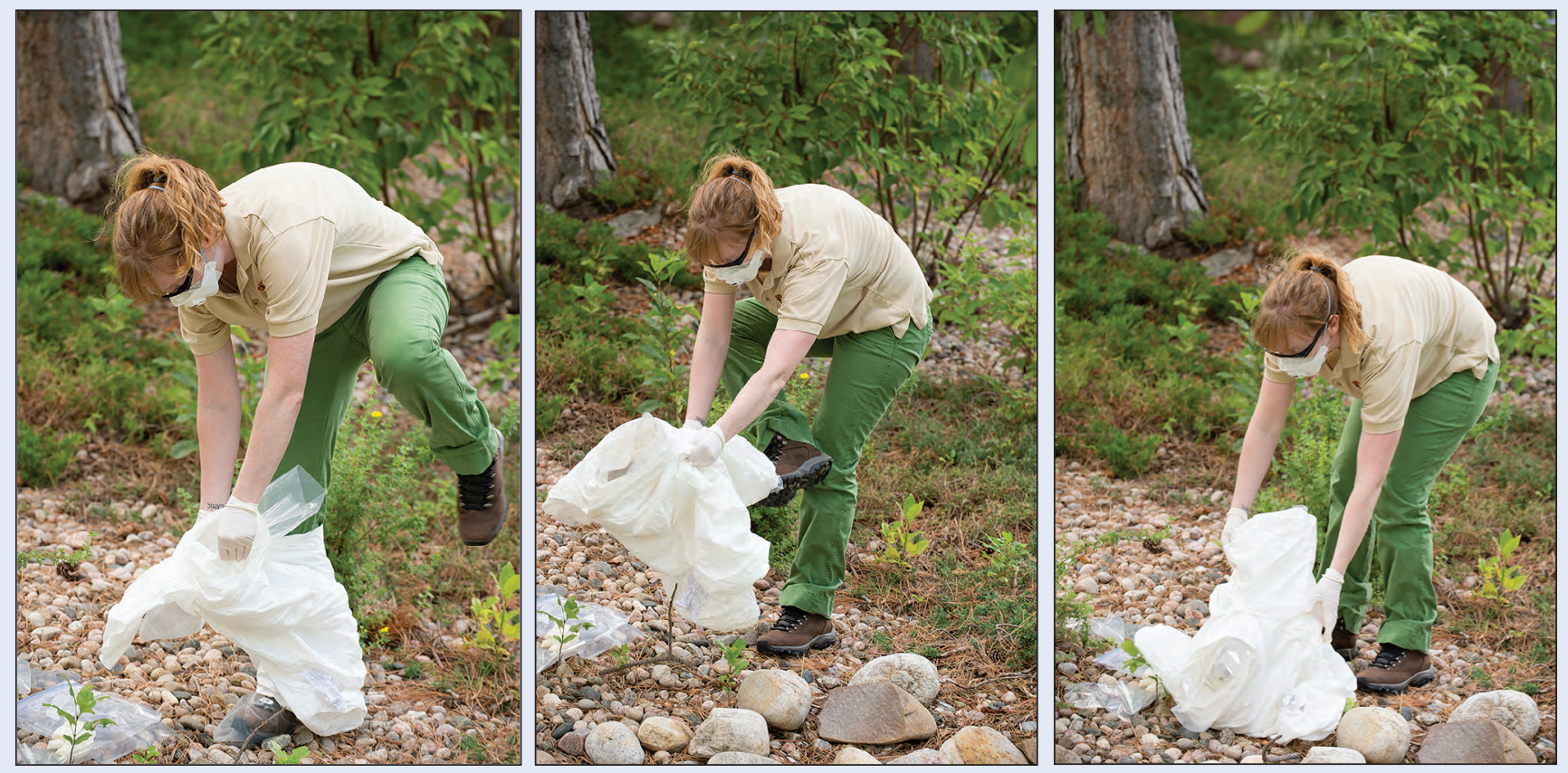
3

Remove the first inner layer of the glove by gripping the palm of one gloved hand with the fingers of the other gloved hand and pulling the glove off. Do not slide a gloved thumb under the cuff of a glove to remove!
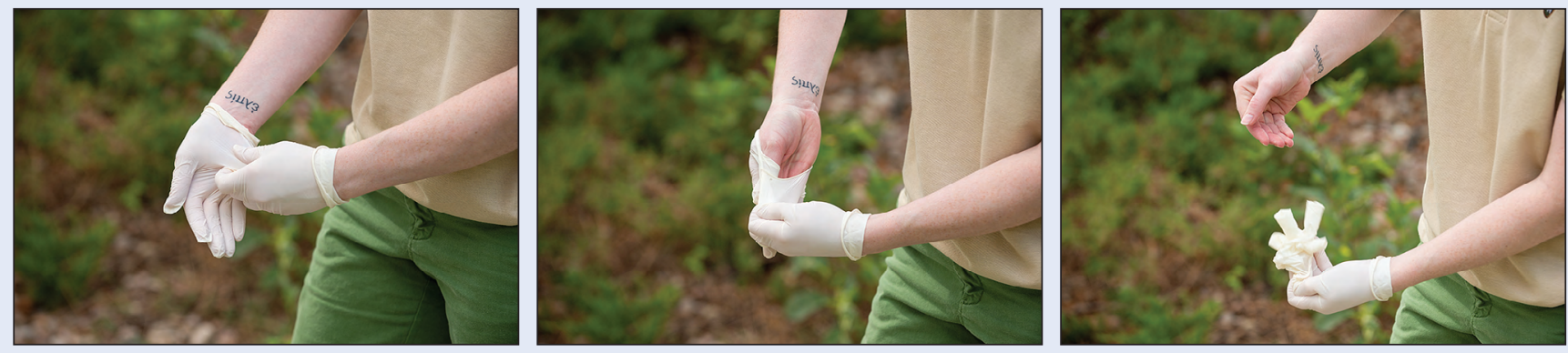

4 Once the first glove has been removed, hold that glove with the remaining gloved hand. Slide the ungloved thumb under the cuff of the gloved hand and pull down, pulling the glove inside out and over the first glove. The first glove will be contained by the inverted second glove. Dispose of the gloves in a bag.
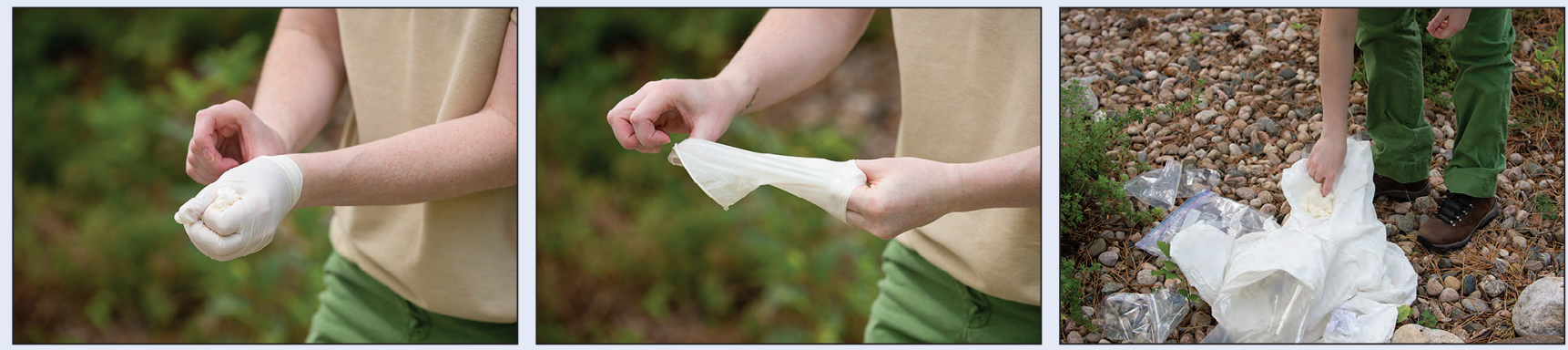

\section{Wash hands thoroughly with soap and water or apply hand sanitizer if soap and water are unavailable. \\ 6 Remove eye protection and the respirator, taking care to not touch the exposed front areas of the PPE.}

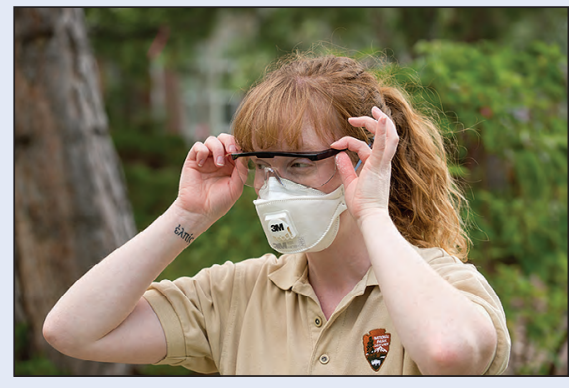

Incorrect-do not touch the exposed front area of the respirator!

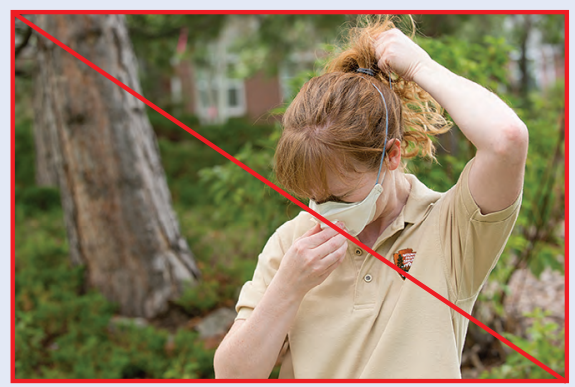

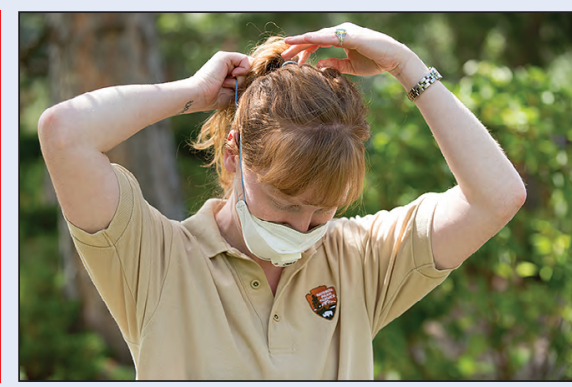

Correct-remove the respirator without touching its front.

7 Don a fresh pair of gloves to disinfect any remaining equipment or reusable PPE. Remove the gloves as in Step 4.

8 Wash hands thoroughly with soap and water or apply hand sanitizer if soap and water are unavailable.

9 As soon as possible, properly dispose of the bagged contaminated PPE according to local regulations and biomedical waste regulations. 


\section{Disinfection}

Disinfection of equipment or the work area will depend greatly on the type of activity that takes place, the exposures of concern, and the jurisdiction of the land or area involved. It is best to consult with the local authorities regarding the appropriate chemicals used and the mechanism of disinfection.

The Center for Food Security and Public Health has many resources on disinfection available, and they are available at http://www.cfsph.iastate.edu/Disinfection/index.php

\section{Workplace Safety and Health Program}

In addition to protecting wildlife workers from hazards, establishing some basic preventive measures will help further minimize workplace exposures. Not all workplace hazards can be eliminated or controlled, but having an employee wellness program in place can help address work-related illnesses and injuries. An employee wellness program for animal workers is described in "Human-Animal Medicine - Clinical Approaches to Zoonoses, Toxicants and other Shared Risks (Rabinowitz and Conti, 2010)." The primary components included in the book serve as one example of an employee wellness program and are summarized here.

\section{Preplacement Screening}

Providing a baseline health screening for wildlife workers is a beneficial component for employee wellness programs. This screening is an opportunity to complete a risk assessment of outlined duties, complete respirator fit testing (if warranted for position), and receive prophylactic vaccinations. Additionally, if an employee is entering a position where allergens and chemical or infectious disease exposures are a concern, specific baseline blood tests may be recommended by the employer or healthcare provider. Preplacement exams may not be provided by all employers; these assessments and the specific components need to be tailored to the organization or agency as well as duty location and employee tasks. An example of a preplacement medical questionnaire that could be modified to be more specific for wildlife workers is provided in appendix 1 .

The questionnaire is figure 12-2 from "Human-Animal Medicine - Clinical Approaches to Zoonoses, Toxicants and other Shared Risks" (Rabinowitz and Conti, 2010).

\section{Vaccinations}

Several vaccinations are recommended for wildlife workers, for human and animal protection.

Rabies.-Wildlife workers performing duties in areas where terrestrial rabies exists and those that handle bats regularly are considered to be in the "frequent risk" category for rabies. These individuals should receive preexposure rabies vaccinations and have rabies titers checked every 2 years. For employees working in a rabies laboratory, titers should be checked every 6 months. Although preexposure vaccination will not eliminate the need for postexposure vaccination in the event of a rabies exposure, it does reduce the necessary followup care and provides some protection in the event an exposure is not detected (Centers for Disease Control and Prevention, 2008).

Influenza.-The seasonal influenza vaccine is particularly beneficial for wildlife workers that have direct contact with waterfowl or domestic poultry. Although seasonal influenza vaccination will not prevent infection with avian influenza $A$ viruses, it can reduce the risk of coinfection with avian and human influenza viruses (Centers for Disease Control and Prevention, 2017).

Tetanus.-All adults should get a tetanus vaccine every 10 years. Wildlife workers may be at increased risk of exposure to tetanus because of frequent contact with soil and the potential to receive an animal bite. Wildlife workers who incur wounds in the field should thoroughly wash out the wound and have their tetanus status evaluated by a healthcare professional because booster recommendations vary (Hamborsky and others, 2015).

Tuberculosis testing.-Many species of wildlife, such as elephants, marine mammals, and nonhuman primates, are susceptible to tuberculosis and serve as a potential source of infection to humans (and vice versa). Depending on the institution, type of work, and species involved, tuberculosis screening is typically recommended on an annual basis (Miller, 2012). 
Hepatitis B.- Some wildlife workers will have direct contact with nonhuman primates in a captive or field setting. Transmission of hepatitis B from humans to nonhuman primates is well documented, and the potential exists for transmission from primates to people. Hepatitis B vaccination is recommended for individuals working with nonhuman primates (American Association of Zoo Veterinarians, 2013).

In a survey of international wildlife workers, respondents expressed interest in periodic health surveillance and enhanced access to medical services for work-related exposures. Additionally, the majority of respondents had been vaccinated for tetanus, rabies, and hepatitis B (Garland-Lewis and others, 2017).

Please note that recommendations may vary for pregnant or immunosuppressed individuals. Consult with a healthcare provider or public health professional regarding appropriate care.

More information on human rabies vaccination protocols and rabies prevention and control is available here:

- Advisory Committee on Immunization Practices' recommendations for human rabies prevention are available at https://www.cdc.gov/mmwr/preview/ mmwrhtml/rr5703a1.htm.

- Advisory Committee on Immunization Practices' current postexposure prophylaxis recommendations are available at https://www.cdc.gov/mmwr/preview/ mmwrhtml/rr5902a1.htm.

- National Association of State Public Health Veterinarians Rabies Compendium are available at http://www. nasphv.org/Documents/NASPHVRabiesCompendium. pdf.

\section{Employee Training}

Appropriate training of a new employee is imperative. As this chapter has highlighted, several hazards pose risks to wildlife workers. OSHA standards for PPE and respiratory protection require employer-provided training. Employers should ensure that training is provided by an experienced colleague or supervisor that is familiar with the duties and hazards of the job. Some topics that should be covered include the following (Rabinowitz and Conti, 2010):

- Animal handling and restraint techniques

- Behavioral cues of animals

- PPE use

- Safe handling of drugs and equipment

- Proper storage of tissue specimens

- Infection control practices

- Education regarding zoonotic diseases and their symptoms in humans
When assessing NPS biologists' perceived risk of zoonoses, there were misconceptions regarding which diseases were actually zoonotic and the human signs associated with them (Nett, 2015). Providing baseline training for new employees and continuing education for all employees on zoonoses, and documenting those trainings, is crucial.

\section{Medical Surveillance}

As noted previously, incident zoonotic infections and deaths among wildlife workers have been documented (Wong and others, 2009; National Park Service, 2008; de St. Maurice, 2017). Because many of these infections are relatively rare and not often considered in a typical medical evaluation, wildlife workers need to be their own advocates. Wildlife workers should be aware of the wildlife diseases in their area, the potential zoonotic diseases they could be exposed to through their work, and the symptoms of those diseases. Self-monitoring for fever and other symptoms after certain activities (for example, dusting prairie dog burrows after a known plague die off) is necessary. Depending on the types of activities and animal species involved, active surveillance for environmental exposures or infectious diseases in wildlife workers may also be warranted, such as tuberculosis screening for those working with primates. More information on medical surveillance is available at https://www.osha.gov/Publications/osha3162.pdf.

Another helpful practice for wildlife workers involves carrying a quick response or medical alert card to accompany an individual who seeks medical attention for a suspected work-related exposure. For example, the U.S. Department of Agriculture's Animal and Plant Health Inspection Service has developed cards for its employees and emergency responders (appendix 2).

\section{Workplace Assessments}

If an employer or worker is concerned about potential workplace exposures or is interested in having an assessment completed at the work site, several resources are available:

- The NIOSH, Health Hazard Evaluation (HHE) Program can investigate what health hazards may be present in a workplace. Assessments may be completed remotely or in person, and NIOSH will provide a written report identifying the issues and recommended modifications to the employer. An HHE can be requested by the employer, employees, or a union official at no cost to the company or organization. NIOSH does not enforce regulations but acts as a resource for employers needing assistance. More information on HHEs is available at https://www.cdc.gov/niosh/hhe/ default.html. An example of an HHE that was completed to assess potential exposures in marine mammal workers is available at https://www.cdc.gov/niosh/hhe/ reports/pdfs/2011-0105-3173.pdf. 
- OSHA also has consultation services available at no cost to small- and medium-sized private sector employers. These consultations are separate from OSHA's enforcement program and do not result in penalties or citations.

For the Federal sector, OSHA offers agency technical assistance requests. If a Federal agency needs technical assistance, the agency can contact the local OSHA Area Office. An Agency Technical Assistance Request may include hazard abatement advice, training, a partial or comprehensive inspection, and (or) program assistance. Although the request is generally considered to be strictly consultative, an agency's subsequent failure or refusal to abate serious hazards may result in an inspection referral.

More information on the OSHA Consultation Program is available here:

- https://www.osha.gov/dcsp/smallbusiness/consult.html.

OSHA regulations relevant to wildlife workers will be covered in the next section.

\section{Safety and Health Regulations for Wildlife Workers}

The U.S Department of Labor's OSHA is responsible for ensuring that America's employers provide a safe and healthful working environment for their workers. OSHA develops and enforces standards and provides technical assistance and cooperative programs to support employers, including worker training. Although there is specific guidance for veterinarians in a clinical setting, wildlife workers may fall into several occupational sectors, including agriculture, forestry and fishing, education, healthcare, and veterinary medicine and other animal care. Several OSHA standards are relevant to wildlife workers, including: veterinarians and biologists in the field. These standards include the following: Bloodborne Pathogen Standard, Personal Protective Equipment Standard, Respiratory Protection Standard, Hazard Communication Standard, Radiation Safety, Recordkeeping, and General Duty Clause OSHA Act of 1970, Section (5)(a)(1).

\section{Bloodborne Pathogen Standard}

OSHA's Bloodborne Pathogens standard

29 CFR 1910.1030 applies to occupational exposure to human blood, body fluids, and other potentially infectious materials, which are well defined in the standard. The standard also applies to exposure to human immunodeficiency virus (HIV)containing cell or tissue cultures, organ cultures, and HIV- or hepatitis B-containing culture medium or other solutions and blood, organs, or other tissues from experimental animals infected with HIV or hepatitis B. Thus, the BBP standard may apply to some wildlife workers, including those in laboratories working with HIV- or hepatitis B-infected animals. Given the potential risk of bloodborne zoonotic disease transmission, the BBP standard may also provide a useful framework for worker protection even in scenarios where compliance is not otherwise required. Implementing best practices, including use of a hierarchy of engineering controls, administrative controls, safe work practices, and PPE, will help prevent occupational exposures to animal blood and other potentially infectious materials. The full text of the BBP standard is available from OSHA's website at https://www.osha.gov/pls/oshaweb/ owadisp.show_document?p_table=STANDARDS\&p_ $\mathrm{id}=10051$. OSHA also provides more information on its Safety and Health Topics page for Bloodborne Pathogens and Needlestick Prevention at https://www.osha.gov/SLTC/ bloodbornepathogens/.

\section{Personal Protective Equipment Standard}

PPE is equipment that is worn to minimize harmful exposures in the workplace. Gloves, respirators, and protective clothing are examples of PPE that wildlife workers frequently use. OSHA's PPE standards (Occupational Safety and Health Administration, 2006) require employers to assess potential hazards, identify appropriate PPE, and provide the PPE that is necessary for workers to accomplish work duties safely and healthfully. If PPE is required, then employers must implement a PPE program that addresses, among other issues, the following topics:

- Hazards in the workplace

- Selection, use, and maintenance of PPE

- Training on appropriate use of PPE

- Program evaluation

Details regarding PPE for wildlife workers are covered in the "Best Practices" section of this chapter. More information on OSHA's PPE Standard is available here:

- https://www.osha.gov/SLTC/personalprotectiveequipment/

- https:/www.osha.gov/pls/oshaweb/owadisp.show document?p_table=STANDARDS\&p_id=9777. 


\section{Respiratory Protection Standard}

OSHA's Respiratory Protection Standard 29 CFR 1910.134 provides guidelines for workers to prevent exposure to transmissible infectious agents through contact, droplet, and airborne routes. OSHA requires that employers provide respirators to employees when needed, and that they establish a written respiratory protection program. The primary objectives of the respiratory protection program include the following:

- Procedures for selecting respirators.

- Medical evaluation of employees using respirators.

- Procedures for fit testing employees with tight-fitting respirators.

- Training employees in the respiratory hazards to which they are potentially exposed.

- Training in selection, use, and maintenance of respirators.

Fit testing is required before initial respirator use, when a different respirator is used, and when changes in the user's physical condition could affect fit. At a minimum, fit testing should be completed annually. Reusable respirators need to be stored properly to avoid damage, and a disposable respirator needs to be used before its expiration date. More information on respirator options, selection, and use is available through OSHA and NIOSH at the following links:

- https://www.osha.gov/dte/library/respirators/faq.html

- https://www.cdc.gov/niosh/npptl/topics/respirators/ factsheets/respfact.html

- https://www.cdc.gov/niosh/npptl/topics/respirators/ disp_part/.

In addition to Federal regulations, the State of California has developed its own Aerosol Transmissible Diseases Standard to prevent employee exposure to zoonotic pathogens. This order is inclusive of State and private sector veterinarians and wildlife workers in California. More information on California's Aerosol Transmissible Diseases Standard is available at https://www.cdph.ca.gov/Programs/CCDPHP/ DEODC/OHB/CDPH\%20Document\%20Library/ATD-Guidance.pdf. More information on OSHA's Respiratory Protection is available at https://www.osha.gov/pls/oshaweb/owadisp. show_document?p_table=STANDARDS\&p_id $=12716$.

\section{Hazard Communication Standard}

OSHA's Hazard Communication Standard

29 CFR 1910.1200 is in place to ensure that workers are aware of and understand the chemical hazards in their workplace and how to protect themselves from such hazards. Injectable and gas anesthetic drugs are one of the most serious chemical hazards for wildlife workers. In 2013, OSHA revised its
Hazard Communication Standard to be consistent with the United Nations Globally Harmonized System of Classification and Labeling of Chemicals. The major changes affiliated with this revision include four categories:

1. Hazard classification - provides specific criteria for classification of hazards.

2. Labels - manufacturers are required to provide labels with the chemical name, a pictogram, and required PPE for handling the chemical.

3. Safety data sheets (formerly material safety data sheets) these sheets now include a 16-section format that includes the potential hazards, first aid measures, and toxicological and ecological information for the chemical.

4. Information and training - employers must provide and document training regarding all the above.

More information on OSHA's Hazard Communication Standard is available at

- https://www.osha.gov/dsg/hazcom/index.html.

More information on Safety Data Sheets is available at

- https://www.osha.gov/Publications/HazComm QuickCard SafetyData.html.

\section{Radiation Safety}

Although not as common in the field as in a clinical setting, ionizing radiation is another OSHA regulation applicable to wildlife workers. If taking radiographs or other forms of potential exposure are part of an employee's duties, employers need to provide the following:

- Training on ionizing radiation and potential health effects

- Limit direct exposures and exposures in restricted areas

- Maintain compliance with dose limits; OSHA's occupational dose limit for ionizing radiation is 1.25 rems per calendar quarter, not to exceed 3 rems in any calendar quarter of a year

- Personnel monitoring through use of film badges, pocket dosimeters, and other equipment whenever a worker is expected to receive a dose of 25 percent of the dose limit

- Appropriate signage regarding radiation equipment

The California Veterinary Medical Board developed a manual on radiation safety that includes these topics as well as protective apparel, darkroom standards, and film developing; it can be accessed at http://www.vmb. ca.gov/forms_pubs/radguide.pdf. More information on OSHA's Ionizing Radiation standards 29 CFR 1910.1096 is available at https://www.osha.gov/pls/oshaweb/owadisp. show_document?p_table=STANDARDS\&p_id $=10098$. 


\section{Recordkeeping}

OSHA defines any injury, illness, or fatality caused by an event or exposure in the employee's work environment as work related. Preexisting conditions that are significantly aggravated by work are also considered work related.

Depending on the specific number of employees and work setting, some employers of wildlife workers may not be mandated to track and report illnesses and injuries to OSHA under 29 CFR 1910.95. However, maintaining work-related injury and illness records is in keeping with best practices. Examples of records that OSHA requires include the following:

- Work-related injuries and illnesses that result in time away from work, restricted work, loss of consciousness, or medical treatment beyond first aid.

- Work-related fatality, inpatient hospitalization of one or more employees, an employee's amputation, or an employee's loss of an eye.

- Other significant work-related health outcomes, diagnosed by a healthcare professional.

Employers can document injury and illness through the use of the following OSHA forms:

- Form 300

- Log of work-related injuries and illnesses

- Details include cause of injury or illness, location of injury or illness, and time away from work

- Form 300A

- Summary of work-related injuries and illnesses

- Annual report of previous year's injuries and illnesses (based on form 300)

- Must be posted in an area visible to employees

- Form 301

- Collects detailed information of an incident

- Used by the employer and workers compensation insurance carrier

- Information can be collected through another route, as long as it captures pertinent information

Electronic reporting to OSHA was implemented in 2017. Employers with more than 250 employees, and those with 20-250 employees in high-risk industries, are required to electronically submit forms to OSHA on an annual basis. Federal agencies must maintain injury and illness records in principally the same format as the private sector as set forth in 29 CFR §1904- Recording and Reporting Occupational Injuries and Illnesses. More information on OSHA's recordkeeping and reporting is available at https://www.osha.gov/ recordkeeping/index.html.

\section{General Duty Clause OSHA Act of 1970, Section (5)(a)(1)}

OSHA's general duty clause covers hazards that are not specifically addressed by other industry standards, such as occupational noise exposure. A potential area of concern for wildlife workers regarding noise exposure is the use of powered remote delivery systems, particularly those that are deployed from helicopters.

For wildlife workers involved in such activities, it is best to refer to aerial capture, eradication, and tagging of animals protocols. Some aerial capture, eradication, and tagging of animals resources are available here:

- U.S. Department of the Interior-Department Manual, "Aerial Capture, Eradication, and Tagging of Animals (ACETA) Handbook" available at https://www.doi. gov/sites/doi.opengov.ibmcloud.com/files/uploads/ ACETA_Handbook_1997.pdf.

- U.S. Fish and Wildlife, "Aerial Capture, Eradication, and Tagging of Animals (ACETA)" available at https:// www.fws.gov/policy/e1330fw4.pdf.

- United States Department of Labor, "Occupational Noise Exposure" available at https://www.osha.gov/ SLTC/noisehearingconservation/standards.html.

- Centers for Disease Control and Prevention, "Hazards to Outdoor Workers": https://www.cdc.gov/niosh/topics/outdoor/.

Specific regulations may vary by institution or agency and local occupational health authorities. Twenty-eight States have OSHA-approved plans that may have different or more stringent standards to achieve OSHA-mandated goals.

\section{Federal Agency Requirements}

Federal agency occupational safety and health program requirements are described in Section 19 of the Occupational Safety and Health Act of 1970 and Executive Order 12196. In addition to complying with OSHA's workplace safety and health regulations, Federal agencies must comply with the program requirements of 29 CFR 1960- Basic Program Elements for Federal Employee Occupational Safety and Health Programs and Related Matters.

Although section 5(a)(1) of the Act, OSHA's General Duty Clause, does not apply to Federal agencies, 29 CFR 1960.8(a)-Agency responsibilities is the equivalent and applies to all Executive Branch departments and independent agencies. Also, unlike the private sector, the definition of employee under 29 CFR 1960.2(g)- Definitions is broad enough to include volunteers. 


\section{Other OSHA Standards}

Many States have their own occupational health agencies, which may have more specific regulations for local industries. Find out more about State and region-specific regulations here:

- https://www.osha.gov/dcsp/osp/

- https://www.osha.gov/dep/leps/leps.html

California has a Veterinary Compliance Assistance site which provides information for the veterinary work sector, including guidance for bloodborne pathogens:

- https://www.vetca.org/index.cfm

- https://www.vetca.org/rmw/osha-bps.php

\section{Conclusions}

Wildlife workers have the potential to be exposed to diverse and numerous hazards as part of their job duties. Although most wildlife worker injuries and deaths are the result of common hazards such as traffic accidents and drownings, wildlife work can present less common hazards that require additional preparation and care to mitigate. Careful planning that includes a job hazard analysis for hazard identification and implementation of the HOCs, standard precautions, adequate preparation that includes training, vaccinations, and proper personal protective equipment procurement and use, and expert execution of job tasks in accordance with State and Federal standards can ensure a safe and healthy working environment. Many resources are available to employees and employers to assist in achieving these goals. Ultimately, awareness of the hazards and active engagement by employers and employees is necessary to maintain a safe and healthy work environment, which has benefits for humans and wildlife alike.

\section{References}

Adjemian, J., Weber, I.B., McQuiston, J., Griffith, K.S., Mead, P.S., Nicholson, W., Roche, A., Schriefer, M., Fischer, M., Kosoy, O., Laven, J.J., Stoddard, R.A., Hoffmaster, A.R., Smith, T., Bui, D., Wilkins, P.P., Jones, J.L., Gupton, P.N., Quinn, C.P., Messonnier, N., Higgins, C., and Wong, D., 2012, Zoonotic infections among employees from Great Smoky Mountains and Rocky Mountain National Parks, 2008-2009: Vector Borne and Zoonotic Diseases, v. 12, no. 11, p. 922-931.

American Association of Zoo Veterinarians, Animal Health and Welfare Committee, 2017, Infectious disease manualInfectious diseases of concern to captive and free ranging wildlife in North America: accessed, March 17, 2017, at https://cdn.ymaws.com/www.aazv.org/resource/resmgr/idm/ idm_updated_march_2020.pdf.

Bosch, S.A., Leong, K., Musgrave, K., Powers, J., Wong, D., 2010, Zoonotic disease risk perception and use of personal protective measures among wildlife biologists - An application of the health belief model: Human Dimensions of Wildlife, v. 15, no. 3, p. 221-228.

Bosch, S.A., Musgrave, K., and Wong, D., 2013, Zoonotic disease risk and prevention practices among biologists and other wildlife workers-Results from a national survey, US National Park Service, 2009: Journal of Wildlife Diseases, v. 49 , no. 3 , p. $475-485$.

Centers for Disease Control and Prevention, 2008, Human rabies prevention-United States, 2008-Recommendations of the Advisory Committee on Immunization Practices: MMWR. Morbidity and Mortality Weekly Report, v. 57, p. 1-26.

Centers for Disease Control and Prevention, 2013, National Occupational Research Agenda-National Healthcare and Social Assistance Agenda-February 2013: Atlanta, accessed March 17, 2017, at https://www.cdc.gov/nora/ comment/agendas/hlthcaresocassist/default.html.

Centers for Disease Control and Prevention, 2016, Standard Precautions for all patient care: Centers for Disease Control web page, accessed April 14, 2020, at https://www.cdc.gov/ infectioncontrol/basics/standard-precautions.html.

Centers for Disease Control and Prevention, 2017, Prevention and treatment of avian influenza A viruses in people: Centers for Disease Control and Prevention web page, accessed March 15, 2017, at https://www.cdc.gov/flu/avianflu/prevention.htm. 
de St Maurice, A., Ervin, E., Schumacher, M., Yaglom, H., VinHatton, E., Melman, S., Komatsu, K., House, J., Peterson, D., Buttke, D., Ryan, A., Yazzie, D., Manning, C., Ettestad, P., Rollin, P., and Knust, B., 2017, Exposure characteristics of hantavirus pulmonary syndrome patients, United States, 1993-2015: Emerging Infectious Diseases, v. 23 , no. 5 , p. $733-739$.

Garland-Lewis, G., Whittier, C., Murray, S., Trufan, S., and Rabinowitz, P.M., 2017, Occupational risks and exposures among wildlife health professionals: EcoHealth, v. 14, no. 1 , p. 20-28.

Hafner, M.S., 2007, Field research in mammalogy-An enterprise in peril: Journal of Mammalogy, v. 88, no. 5, p. 1119-1128.

Hamborsky, J., Kroger, A., Wolfe, C., eds., 2015, Epidemiology and prevention of vaccine-preventable diseases: Centers for Disease Control and Prevention Course Textbook, chapter 21, 12 p, accessed March 15, 2017, at https://www.cdc. gov/vaccines/pubs/pinkbook/downloads/tetanus.pdf.

Miller, J.M., Astles, R., Baszer, T., Chapin, K., Carey, R., Garcia, L., Gray, L., Larone, D., Pentella, M., Pollock, A., Shapiro, D. S., Weirich, E., Wiedbrauk, D., 2012, Guidelines for safe work practices in human and animal medical diagnostic laboratories: MMWR Morbidity and Mortality Weekly Report, v. 61, p. 1-101.

National Park Service, 2008, Safe work practices for employees handling wildlife: Reference Manual 50B section 4.15, 239-254, accessed March 14, 2017, at https://www.nps.gov/ policy/RM50Bsection4.pdf.

National Park Service, 2014, Safe practices to avoid zoonotic disease from wildlife - Quick reference guide: National Park Service quick reference guide, $26 \mathrm{p}$.

Nett, R.J., Witte, T.K., Holzbauer, S.M., Elchos, B.L., Campagnolo, E.R., Musgrave, K.J., Carter, K.K., Kurkjian, K.M., Vanicek, C.F., O’Leary, D.R., Pride, K.R., and Funk, R.H., 2015, Risk factors for suicide, attitudes toward mental illness, and practice-related stressors among US veterinarians: Journal of the American Veterinary Medical Association, v. 247, no. 8, p. 945-955.
Occupational Safety and Health Administration, 2002, Job hazard analysis guide - OSHA 3071: Occupational Safety and Health Administration booklet, accessed April 14, 2020, at https://www.osha.gov/Publications/osha3071.pdf.

Occupational Safety and Health Administration, 2006, Major requirements of OSHA'S respiratory protection standard 29 CFR 1910.134: Office of Training and Education, 8 p.

Occupational Safety and Health Administration, 2016, Recommended practices for safety and health programs - OSHA 3885: Occupational Safety and Health Administration guidelines, accessed April 14, 2020, at https://www.osha. gov/Publications/OSHA3885.pdf.

Rabinowitz, P.M., and Conti, L.A., 2010, Human-animal medicine - Clinical approaches to zoonoses, toxicants, and other shared health risks: Maryland Heights, Md., Saunders, $432 \mathrm{p}$.

Sasse, D.B., 2003, Job-related mortality of wildlife workers in the United States, 1937-2000: Wildlife Society Bulletin, v. 31, no. 4, p. 1015-1020.

Stoewen, D.L., 2015, Suicide in veterinary medicine-Let's talk about it: The Canadian Veterinary Journal, v. 56, no. 1, p. 89-92.

Williams, C.J., Scheftel, J.M., Elchos, B.L., Hopkins, S.G., and Levine, J.F., 2015, Compendium of veterinary standard precautions for zoonotic disease prevention in veterinary personnel: Journal of the American Veterinary Medical Association, v. 247, no. 11, p. 1252-1277.

Wong, D., Wild, M.A., Walburger, M.A., Higgins, C.L., Callahan, M., Czarnecki, L.A., Lawaczeck, E.W., Levy, C.E., Patterson, J.G., Sunenshine, R., Adem, P., Paddock, C.D., Zaki, S.R., Petersen, J.M., Schriefer, M.E., Eisen, R.J., Gage, K.L., Griffith, K.S., Weber, I.B., Spraker, T.R., and Mead, P.S., 2009, Primary pneumonic plague contracted from a mountain lion carcass: Clinical Infectious Diseases, v. 49 , no. 3 , p. e33-e38. 


\section{Appendix 1. Example of a Preplacement Medical Questionaire Suitable for Modification}

\begin{tabular}{|c|c|}
\hline \multicolumn{2}{|c|}{ Confidential Risk Assessment and Medical Questionnaire for Animal Workers } \\
\hline \multicolumn{2}{|c|}{ Name: $\longrightarrow$ Gender: $\square$ Male $\square$ Female Date of Birth: } \\
\hline \multicolumn{2}{|c|}{ Occupational exposure to animals and animal tissue: } \\
\hline \multicolumn{2}{|c|}{$\square$ Amphibian $\square$ Bird $\square$ Cat $\square$ Cattle $\square$ Dog $\square$ Ferret $\square$ Fish $\square$ Goat $\square$ Horse $\square$ Insect } \\
\hline \multicolumn{2}{|c|}{$\square$ Nonhuman primate $\square$ Pig $\square$ Rabbit $\square$ Reptile $\square$ Rodent $\square$ Sheep $\square$ Wildife species (please list): } \\
\hline \multicolumn{2}{|c|}{$\square$ No animal or animal tissue contact } \\
\hline \multicolumn{2}{|c|}{ Other hazardous exposures: } \\
\hline \multicolumn{2}{|c|}{ 口Human blood/tissue $\square$ Chemicals (please list): } \\
\hline \multicolumn{2}{|c|}{$\square$ Dust $\square$ Noise $\square$ Radiation $\square$ Heavy lifting $\square$ Other (please specify): } \\
\hline \multicolumn{2}{|c|}{ Personal protective equipment worn: } \\
\hline \multicolumn{2}{|c|}{$\square$ Mask/respirator (type): $\_\square$ Gloves $\square$ Other (please specify): } \\
\hline \multicolumn{2}{|c|}{ Pots, other nonoccupational animal exposures: } \\
\hline \multicolumn{2}{|c|}{ Please state whether outside of work you have contact with any of the following: } \\
\hline \multicolumn{2}{|c|}{$\square$ Bird $\square$ Cat $\square$ Dog $\square$ Ferret $\square$ Fish $\square$ Horse $\square$ Rabbit $\square$ Reptile $\square$ Rodent $\square$ Other (please list): } \\
\hline \multicolumn{2}{|c|}{$\begin{array}{l}\text { Medical conditions: } \\
\text { Please list known allergies to medications, animals, or other environmental allergens: }\end{array}$} \\
\hline \multicolumn{2}{|c|}{ Please list known allergies to medications, animals, or other environmental allergens: } \\
\hline \multirow{3}{*}{\multicolumn{2}{|c|}{$\begin{array}{l}\text { Please list whether you have any of the following: } \\
\square \text { Asthma } \square \text { Rhinitis } \square \text { Eczema } \square \text { Other skin disease } \square \text { Diabetes } \square \text { Cancer } \square \text { Recurrent infections } \square \text { Other medical } \\
\text { conditions that could compromise immune system } \square \text { Heart murmur } \square \text { Hepatitis } \square \text { Back problems } \square \text { Other musculo- } \\
\text { skeletal problems } \square \text { Depression or anxiety } \\
\text { Please list current medications (prescription, over-the-counter, and supplements): }\end{array}$}} \\
\hline & \\
\hline & \\
\hline \multicolumn{2}{|l|}{ Symptoms: } \\
\hline \multicolumn{2}{|c|}{ Please check if you have any of the following symptoms: } \\
\hline \multicolumn{2}{|c|}{$\begin{array}{l}\square \text { Cough } \square \text { Shortness of breath } \square \text { Wheezing } \square \text { Runny/itchy eyes } \square \text { Runny/itchy/congested nose/sneezing } \square \text { Skin rash } \\
\square \text { Musculoskeletal pain } \square \text { Persistent diarrhea } \square \text { Weight loss } \square \text { Unexplained fevers } \square \text { Depression or anxiety } \square \text { Other } \\
\text { (please list): }\end{array}$} \\
\hline \multicolumn{2}{|c|}{$\begin{array}{l}\text { Do you feel any of your symptoms are related to work? } \square \text { Yes } \square \text { No } \\
\text { Immunizations/uberculosis testing: }\end{array}$} \\
\hline \\
\hline \multicolumn{2}{|c|}{ Please state your most recent immunizations and tuberculosis (TB) test and date: } \\
\hline Immunization & Date \\
\hline \multicolumn{2}{|l|}{ Tetanus } \\
\hline \multicolumn{2}{|l|}{ Rabies } \\
\hline \multicolumn{2}{|l|}{ Influenza } \\
\hline \multicolumn{2}{|l|}{ Hepatitis B } \\
\hline TB testing & \\
\hline
\end{tabular}




\section{Appendix 2. Examples of Quick Response or Medical Alert Cards}

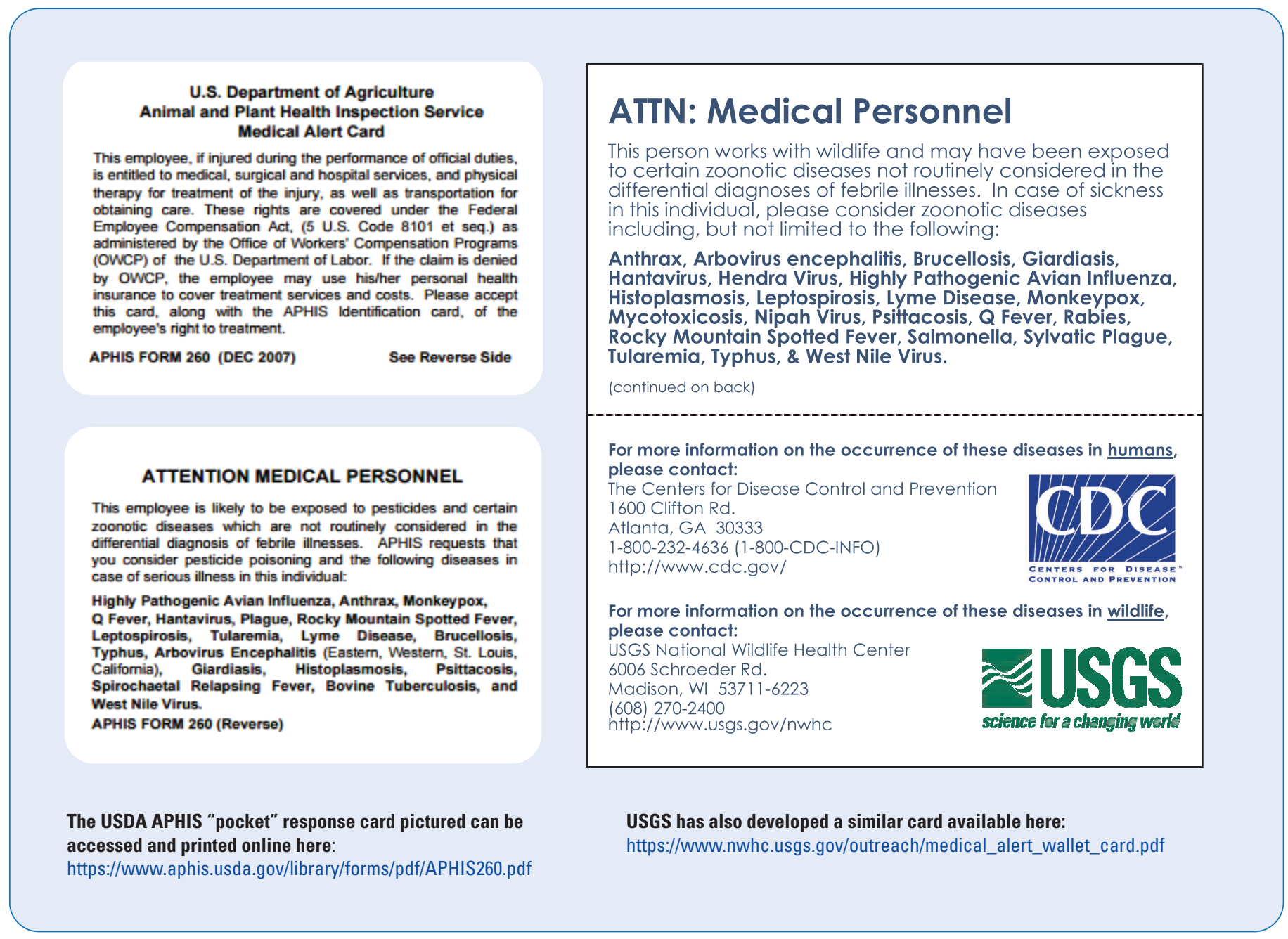


Please note: These procedures may be revised as the situation develops.

\title{
QUICK RESPONSE CARD
}

\section{Ensuring responder safety is the first priority at all times.}

\begin{abstract}
Always know the hazards of the job, and how to protect yourself - read the SOP
Buddy system - know where your buddy is during on-farm activities

Care - take care of yourself - ppe, rest breaks, water, food, cool off

Defensive Driving - seat belts, no use of any communications devices while driving. Carry a vehicle accident kit and a first aid kit.

EAP - Employee Assistance Program - (800) 222-0364 (24 hrs/day, 7 days/week)

Fatigue - get plenty of rest and sleep - don't drive when you're tired

Get the Standard Operating Procedures (SOP) and understand them
\end{abstract}

Program phone numbers for your Incident Supervisor and the Safety Officer into your phone.

Make sure Location Services is enabled on your phone. Know the location of the nearest hospital.

\section{See your Safety Officer or Incident Supervisor for more information on: \\ http://sp.we.aphis.gov/vs/sites/SPRS/NPIC/SiteAssets/SitePages/HPAI/Responder\%20Safety\%20\%20Health\%20for\%20ICS\%20Deployment 20 \%20May\%202015\%20Final.pdf (requires a VPN connection)}

Heat stress

Rest breaks - take them!

Accident/injury/illness reporting

Workers Compensation (OWCP)

Check-out/check-in procedures

Respirator use

Weather

Chemical safety
Medical clearance

Respirator training and fit testing

Personal protective equipment

Daily briefing

Incident action plan

Emergency procedures

Uncooperative individuals

Standard operating procedures

\section{Other Important Stuff}

- Tell your Incident Supervisor or Safety Officer immediately if you're injured or feel sick.

- Report hazards immediately.

- Don't work more than 12 hours without specific supervisor instructions.

- Take breaks at least every 2 hours to cool off and drink fluids.

- If your urine is yellow, drink more water.

- Watch for weather, ticks, mosquitos, dogs, deer on the highways, hostile owners.

- Practice biosecurity: prevent contamination, clean, disinfect.

- Watch your step - booties can be slippery.

- Campylobacteriosis and Salmonellosis are among the zoonotic diseases of concern when working with poultry. Wash hands with soap after contact with animal feces. All food and water are to be consumed on the clean side of the clean/dirty line.

- Don't enter barns during/after $\mathrm{CO}_{2}$ operations until Incident Supervisor or safety officer declares it's safe. Stay out of foam during foaming operations.

- Shower and shampoo as soon as possible. Clean and disinfect the vehicle before leaving infected premises, and wash the vehicle after leaving the premises.

- Biosafety is very important, but don't forget about other hazards: 
- Electrical, machinery/vehicles, enclosed spaces/tanks/silos/pits, chemicals including disinfectants/detergents, high pressure sprayers, ammonia, walking and working surfaces.

- Wear visible ID while conducting surveillance.

- Wash hands frequently. Don't share food or drink.

- Try to get a healthy diet. Minimize alcohol intake, especially in hot weather. Build up heat resistance over a period of several days.

\section{Personal Protective Equipment (PPE)}

Wear proper personal protective equipment (PPE) for the job you are doing. Don't remove your PPE until you're back at the clean/dirty line. Full PPE is required for work done on infected premises:

- Tyvek coveralls (Tychem coveralls for foam depopulation)

- Rubber boots or boot covers

- N95 respirators as a minimum

- Safety goggles or safety glasses with sideshields

- Gloves (double) (e.g., inner latex gloves; outer glove)

- Head bonnet and/or hardhat

$\circ$ Hearing protection (disposable ear plugs) where noise is a hazard

\section{What to do if your PPE is breached or compromised:}

- If your PPE is breached (torn or obviously damaged), take your buddy with you and leave the work area, doff PPE, decontaminate yourself, and don new PPE. A minor tear might be "fixable" with duct tape after you've used alcohol gel on your skin. If your skin was cut or scraped, you should shower, then apply first aid. Let your Incident Supervisor know as soon as you can, but at least by the end of your shift.

- If you think your PPE is compromised (possibly damaged or not working properly) at any time the work being done, stop work immediately. Contact your Incident Supervisor and/or the Safety Officer for guidance. If this requires leaving the work area, take your buddy with you.

\section{More on the Buddy System}

While in the Hot or Exclusion Zone, use the buddy system. Work in pairs and stay in close visual contact and summon rapid assistance in case of an emergency. The responsibilities of workers using the buddy system include:

o remaining in close visual contact with their partner,

$\bigcirc$ providing their partner with assistance as needed or requested,

$\bigcirc$ observing their partner for signs of heat stress or other difficulties,

$\bigcirc$ periodically checking the integrity of partner's PPE, and

$\bigcirc$ notifying the site manager or other site personnel if emergency assistance is needed.

All responders must follow safety and health guidelines to protect themselves and everyone around them. You risk more than your own health and safety, as well as biosecurity, if you do not.

APHIS Emergency Mobilization Guide, APHIS 1050, March 3, 2014

http://www.aphis.usda.gov/emergency response/downloads/APHIS\%20Emergency\%20Mobilization\%20Guide.pdf

Highly Pathogenic Avian Influenza Standard Operating Procedures: 8. Health and Safety \& Personal

Protective Equipment, FADPReP, USDA APHIS, January 2014

http://www.aphis.usda.gov/animal health/emergency management/downloads/sop/sop hpai health safety.pdf

Highly Pathogenic Avian Influenza Response Plan -- The Red Book, FADPReP, USDA APHIS,

September 2012

http://www.aphis.usda.gov/animal health/emergency management/downloads/hpai response plan.pdf

Quick Response (QR) codes require a Smartphone with an enabled app-recommend "Redlaser Barcode Scanner". Access to SharePoint also requires the Cisco AnyConnect app on your Smartphone to establish a VPN connection. 
Publishing support provided by the U.S. Geological Survey Science Publishing Network, Madison and Rolla Publishing Service Centers

For additional information contact; Director, National Wildlife Health Center U.S. Geological Survey

6006 Schroeder Road

Madison, WI 53711-6223

https://www.usgs.gov/centers/nwhc 


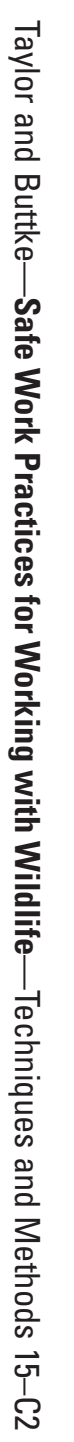

